Synthesis, part of a Special Feature on Practicing Panarchy: Assessing Legal Flexibility, Ecological Resilience, and Adaptive Governance in U.S. Regional Water Systems Experiencing Climate Change

\title{
Understanding and applying principles of social cognition and decision making in adaptive environmental governance
}

\author{
Daniel A. DeCaro ${ }^{1}$, Craig Anthony (Tony) Arnold ${ }^{2}$, Emmanuel Frimpong Boamah ${ }^{3}$ and Ahjond S. Garmestani ${ }^{4}$
}

\begin{abstract}
Environmental governance systems are under greater pressure to adapt and to cope with increased social and ecological uncertainty from stressors like climate change. We review principles of social cognition and decision making that shape and constrain how environmental governance systems adapt. We focus primarily on the interplay between key decision makers in society and legal systems. We argue that adaptive governance must overcome three cooperative dilemmas to facilitate adaptation: (1) encouraging collaborative problem solving, (2) garnering social acceptance and commitment, and (3) cultivating a culture of trust and tolerance for change and uncertainty. However, to do so governance systems must cope with biases in people's decision making that cloud their judgment and create conflict. These systems must also satisfy people's fundamental needs for self-determination, fairness, and security, ensuring that changes to environmental governance are perceived as legitimate, trustworthy, and acceptable. We discuss the implications of these principles for common governance solutions (e.g., public participation, enforcement) and conclude with methodological recommendations. We outline how scholars can investigate the social cognitive principles involved in cases of adaptive governance.
\end{abstract}

Key Words: adaptive governance; cognition; cooperation; environmental law; legitimacy; social decision making

\section{INTRODUCTION}

Environmental governance systems establish a framework for societal cooperation and stewardship of Earth's vital ecosystems. These institutions are under pressure to adapt because of stressors like climate change, which affect social-ecological systems (SESs) in complex and unpredictable ways (Arnold and Gunderson 2013). Legal and institutional scholars are currently exploring ways to facilitate adaptive governance. For example, scholars involved in the Adaptive Water Governance Project (Cosens et al. 2014a) have developed conceptual frameworks (Ruhl 2011, DeCaro et al. 2017) and some novel legal reforms (e.g., Craig and Ruhl 2014) to guide this transition toward more adaptive environmental governance. We review aspects of social cognition and decision making, which may constrain society's capacity for cooperation and change, and strongly influence adaptive governance. Environmental laws and broader governance processes based on faulty assumptions about human behavior may be ineffective or backfire (McKenzie-Mohr 2000, Cornforth 2009), hindering adaptation.

\section{SYNTHESIS APPROACH}

\section{Adaptive environmental governance}

We define environmental governance as all actions to decide, design, implement, and enforce rule systems to oversee the use of SESs (Chaffin et al. 2014a). Environmental governance involves both formal and informal procedures and activities, such as official policies and legal frameworks (formal), and everyday practice and social norms (informal; Pahl-Wostl 2009). Many decision makers are involved in governance, including anyone who holds a stake in the problem, its creation or solution, e.g., government officials, grassroots organizers, scientists, landowners, and members of the general public (e.g., Larson et al. 2013). These actors may fulfill many roles, ranging from rule makers and enforcers to interpreters and compliers (Ostrom 2005). The psychological processes of these actors are important because they shape environmental governance (Shivakumar 2005, Ostrom 2010).

Because of certain assumptions about complex systems, formal environmental governance systems (e.g., federal laws) have traditionally treated SESs as if they are linear and relatively unchanging (Clarvis et al. 2014, Green et al. 2015). This approach has led to overly rigid and narrow policies, which may be outdated and poorly matched to complex SESs (Arnold and Gunderson 2013, Cosens et al. 2014a). Shortcomings in environmental governance can increase societal conflict and impede cooperative problem solving (e.g., Gunderson et al. 2014).

Adaptive governance seeks to address these limitations with legal and institutional systems (rules, norms, and procedures) that embrace the complexity of SESs (Folke et al. 2005, Ruhl 2011, Arnold and Gunderson 2013, Cosens et al. 2014b). Adaptive governance systems are characterized by experimentation, flexibility, creative problem solving, social learning, participatory democracy, and diversity in methods, approaches, and actors (Armitage 2007, Huitema et al. 2009, Chaffin et al. 2014a). Diversity, flexibility, and innovation may enable governance systems to respond to stressors like climate change (Ruhl 2011).

Scholars from the Adaptive Water Governance Project recently proposed that traditional centers of authority (e.g., federal, state, local, and regional governments) can use certain legal, administrative, financial, technical, and democratic tools to increase governance flexibility and empower diverse stakeholders to collectively govern SESs (Cosens 2017, DeCaro et al. 2017). For example, instead of adhering to rigid fixed water allocation rules, which establish specific historical water rights in perpetuity, these rules can be based on decision-making guidelines (e.g.,

\footnotetext{
${ }^{1}$ Department of Urban and Public Affairs, Department of Psychological and Brain Sciences, University of Louisville, ${ }^{2}$ Brandeis School of Law, Department of Urban and Public Affairs, and Center for Land Use and Environmental Responsibility, University of Louisville, ${ }^{3}$ Department of Urban and Public Affairs, University of Louisville, ${ }^{4}$ U.S. Environmental Protection Agency
} 
proportional allocations, yearly planning) that give stakeholders more autonomy and flexibility to tailor their solutions to emergent social-ecological conditions (Schlager and Heikkila 2011). As another example, the federal U.S. Administrative Procedures Act, which governs government decision making and public engagement, could be amended to create more robust legal supports for community-based governance and publicgovernment collaboration (Bingham 2009, 2010). Finally, environmental regulations could be updated periodically in light of new scientific findings (Clarvis et al. 2014, Craig and Ruhl 2014).

\section{Social cognition}

The success of solutions like these will hinge on multiple factors that affect readiness for change, cooperation, and compliance in societies (Dietz et al. 2003, Armitage 2007). We examine adaptive environmental governance through a lens of social cognition (Lee and Harris 2013), cooperation (Parks et al. 2013), and decision making (Cornforth 2009).

Governance systems are socially constructed, so their design, function, and performance are affected by social cognition and decision making (e.g., Tyler 1990, Cornforth 2009). There are many psychological analyses of environmentally responsible behavior (Kollmuss and Agyeman 2002, Cornforth 2009, Steg and Vlek 2009), and some have focused on adaptation to climate change (Moser and Ekstrom 2010, Swim et al. 2011). However, few have considered psychological dimensions of adaptive environmental law and governance (Castro 2012).

We highlight the social cognitive and decision-making aspects of adaptive environmental governance. We show how social systems and processes, like news media, popular discourse, and group relations (e.g., prejudice, competition), interact with human psychology to shape adaptive governance. When legal innovations are introduced, these mediating social systems debate and reinterpret them, fundamentally transforming their practical and symbolic meaning (Silbey 1989). These alterations ultimately affect social acceptance (Moghaddam 2008), implementation (Castro and Batel 2008), and outcomes (Castro 2012). As will be shown, adaptive governance is also influenced by perceptions of legitimacy (Tyler 2006) and fundamental social-psychological needs, such as security and procedural justice, i.e., decisionmaking fairness (Sheldon et al. 2001, Tyler 2006).

\section{General decision making}

To synthesize these concepts and understand how they influence decision making in adaptive governance, we build on a framework introduced by Moser and Ekstrom (2010). The framework outlines three general decision making steps that may be involved in climate change adaptation: (1) understanding, (2) planning, and (3) managing. During understanding, decision makers initially define the problem and search for more information. During planning, decision makers set goals and develop solutions to the problem, as currently defined. During management, decision makers implement and potentially monitor the chosen solutions.

These general steps help us to conceptualize when decisions may go wrong. A decision can be stopped prematurely or conducted poorly at any step (Moser and Ekstrom 2010). For example, in one study on collaborative water governance, disagreement about what constituted a "watershed" (Step 1 Understanding) altered the types of solutions that were considered (Step 2 Planning), and this resulted in a less innovative, ecologically worse solution (Vreudenhill et al. 2010).

We illustrate how cognitive and social cognitive biases can disrupt the decision-making process to adversely affect adaptation. We also approach this analysis from the perspective of societal cooperation. The idea of a complex cooperative dilemma captures the fundamental social-psychological problem society faces when dealing with major societal issues like climate change adaptation. This theoretical lens reveals relevant psychological processes involved in society's struggle for adaptive environmental governance.

\section{SOCIETAL COOPERATION IN ADAPTIVE GOVERNANCE}

From a social-psychological standpoint, the underlying problem faced in adaptive environmental governance is one of cooperation and coordination in a complex social dilemma (Dietz et al. 2003, Armitage 2007). Social dilemmas are situations in which there are competing motivations, within oneself and the broader society, to pursue narrow self-interest versus the collective interest or common good (Hardin 1968, Parks et al. 2013). This problem contributes to the challenge of understanding, planning, and managing (i.e., deciding) how to govern SESs.

Basic characteristics and challenges of societal cooperation have been extensively described in social science (see Hardin 1968, Parks et al. 2013 for review). The purpose of the current article is not to provide a detailed overview of cooperative decision making in social dilemmas or discuss new ways to conduct cooperative studies (see, for example, Bowles 2008, Poteete et al. 2010, Anderies et al. 2011). Instead, by participating in the Adaptive Water Governance Project, which was a comprehensive legal study of six U.S. water basins (Cosens et al. 2014a), we observed that some ecologists, policymakers, and legal scholars were unaware of core cooperative dilemmas involved in adaptive environmental governance. By highlighting these dilemmas, we draw much-needed attention to crucial dimensions of social cognition and decision making that fundamentally shape adaptive environmental governance.

Cooperative dilemmas have received considerable attention in water governance (e.g., Schlager and Heikkila 2011, Larson et al. 2013, Sarker 2013). However, few studies examine water governance from a legal-psychological standpoint. Doing so may reveal essential design features for adaptive environmental governance, because governance solutions need to be designed with people's psychological makeup in mind (e.g., Ostrom 1998, Castro 2012, Parks et al. 2013).

Three cooperative challenges

Adaptive environmental governance poses at least three cooperative challenges that need to be addressed in legal and institutional design: (1) encouraging collaborative problem solving despite inherent conflict, (2) garnering social acceptance and commitment, and (3) cultivating a culture of tolerance for change and uncertainty, while improving legitimacy and helping to secure society through law and order. 
1. Adaptive governance is a contested cooperative dilemma (Dietz et al. 2003, Huitema et al. 2009, Cote and Nightingale 2012). Multiple stakeholders must find ways to move beyond serious conflict over resources, opportunities, and ideologies to achieve mutually beneficial social and ecological outcomes (Fabinyi et al. 2014). Environmental laws, legal decisionmaking procedures, regulatory and enforcement mechanisms, and other aspects of legal systems (e.g., litigation) must encourage cooperation amid conflict (e.g., Ostrom 1971, 1994, Arnold 2004, Marshall 2008).

2. Adaptive governance requires some voluntary commitment and psychological endorsement of the very idea of adaptation for new policies to be effective (Castro 2012, DeCaro and Stokes 2013). Legal scholars should be aware of the basic social-psychological barriers to cooperation (e.g., Tyler 2006, Cornforth 2009, Castro 2012), but recognize that legal systems cannot directly overcome all the barriers (Winter 2000, Stern 2011). Law has an important but specific role to play. Scholars should explore ways to encourage acceptance directly as well as enable other societal systems and governance processes, like community-based governance (Ostrom 2010), quasi-legislative and -judicial processes (Bingham et al. 2005), and public participation (von Korff et al. 2010) to contribute to adaptation, reinforcing the law (DeCaro et al. 2017).

3. Some societal stakeholders may perceive change as a threat, simply because change is uncertain, alters existing power relationships, and disrupts their current lifestyle (Winter 2000, Cornforth 2009). Mitigating this problem may be the primary role of law, from a psychological standpoint. Governance systems can establish basic ground rules that help individuals cope with these perceived threats and maintain security even amid change (Cosens et al. 2017). Adaptive governance systems must balance fundamental social-psychological needs for stability and predictability, which often oppose change, against flexibility and innovation. Otherwise, societal stakeholders may reject change, exacerbating conflict (Craig et al. 2017). As discussed later, perceptions of legitimacy are crucial to this balance: legitimacy can create a sense of trust, which helps society endure difficult and uncertain times (Tyler 2006, Cosens 2013).

We argue that the principles of decision making reviewed (see Table 1) influence adaptive governance specifically by affecting how well governance systems address each of these problems. In other words, problems in adaptive governance stem in large part from problems in decision making (see also Moser and Ekstrom 2010). With these foundational concepts outlined, we next discuss each of the (a) cognitive biases, (b) social cognitive principles, and (c) principles of legitimacy. We illustrate how these psychological processes influence important decisions and adaptive governance processes. We also discuss implications for common governance solutions. Afterward, we synthesize these findings and outline recommendations for future research, encouraging scholars to study how these principles influence outcomes at key decision points in case studies of adaptive governance.

\section{COGNITIVE BIASES}

Fundamental shortcomings in the way human decision makers process information influence adaptive governance (see Table 1). These cognitive biases are also important because, they make people more susceptible to certain kinds of social influence, which create social barriers to adaptation.

Human decision making is plagued by cognitive biases. These biases occur because people have incomplete knowledge, time, and material resources; they also have limited cognitive mental resources (i.e., cognitive capacity) to carry out complex cognitive calculations (Kahneman 2003). Human decision making is also fragmented. Decisions are performed by multiple subsystems (e.g., motivation, perception, memory, and attitude formation), and they do not always operate effectively or work well together (Medin and Bazerman 1999, Camerer and Loewenstein 2004). There are many cognitive biases involved in environmentally irresponsible decisions (Kollmuss and Agyeman 2002, Cornforth 2009, Swim et al. 2011). We focus on biases that influence people's readiness for change and their ability to understand complex social-ecological problems (see Rachlinski 2000, Moser and Ekstrom 2010 more generally).

\section{Mental models (cognitive frames)}

Before choosing environmental policies, decision makers first define the situation (Moser and Ekstrom 2010). These mental models greatly affect subsequent decisions, because they make certain aspects of a decision situation more salient, constraining the information and actions that are perceived as relevant (Beach 1998, Klein 1999). Overly rigid or inaccurate mental models can impede innovation and lead to faulty conclusions (Goldstein 2011), especially when dealing with complex topics like SESs and climate change (Ostrom 2005, Weber and Stern 2011).

When decision makers deal with complex issues, they often use cognitive shortcuts, or heuristics. Heuristics simplify a problem, making it easier to understand (Gigerenzer and Todd 1999), but they may also lead to errors (Kahneman 2003). These errors can hinder progress in environmental governance (Cornforth 2009 , Weber and Stern 2011, Rachlinski 2012).

For example, according to the rational choice model of human decision making, people are too selfish and incapable to solve complex societal problems themselves (Hardin 1968). A powerful centralized government must take control (Hobbes 1651/1909). This view has dominated environmental governance for decades (Peluso 1993, Adams and Hulme 2001). However, evidence strongly suggests this view is not entirely correct: people can successfully self-govern and contribute to cooperative solutions under the right conditions (Ostrom 1990, 2010). According to Ostrom (1998, 2010) and Shivakumar (2005), unquestioned belief in rational choice theory has prevented experts and traditional governments from supporting useful forms of public participation and communitybased governance that could contribute to adaptive environmental governance (see Bingham 2009, 2010 for legal perspective). For instance, Australia's National Conservation Strategy includes provisions for increased community-based management of water resources. However, these provisions have been undermined by government officials because they refuse to relinquish actual authority to local stakeholders (land-care groups), or provide necessary support (Marshall 2008; see Castro and Batel 2008, Quinn 2011 for more examples). 
Table 1. Cognitive and Social Cognitive Principles.

Cognitive Principles Mental Models
Simplistic mental representations of complex problems can lead to inaccurate conclusions that adversely affect policy design, cooperation, and compliance.

(A): Watershed systems and problems can be conceptualized, or framed, in multiple ways. These frames may be difficult to reconcile and may focus attention on particular solutions, preventing consideration of other, more novel options. (B): Simple mental models (e.g., equating greenhouse gases with pollution) influence policy and can lead to popular misconceptions that reduce acceptance.

(C): Simple representations may lead to overly simple solutions, or panaceas.

Loss Aversion
Social Cognitive Principles Social Framing

Social Representations ${ }^{1}$

Symbolic Policy
Political factions, leaders, and other interest groups in society may portray important issues and policies (e.g., alternative energy) as a threat or loss to a particular social group (e.g., the Liberal's war on coal) to increase public resistance and mobilize these social groups.

Environmental laws and governance systems are subjectively interpreted and reshaped through popular discourse and everyday practice. These social representations of governance influence the feasibility, trajectory, and impact of new environmental laws and novel governance interventions. Examples:

(A): Agreeing in principle: tendency to agree with something in principle (e.g., biodiversity protection) but disagree with its concrete application (e.g., enforcement of the U.S. Endangered Species Act on one's own property).

(B): Equivocation: equating one thing (e.g., information campaigns) with another (e.g., public participation) to undercut the law, shirk responsibility, place blame on others, or erode the perceived legitimacy of others' legal claims or rights. Actors (e.g., politicians, government agencies) may engage in symbolic policy gestures designed to placate particular social groups, deceive, or mobilize constituents, often for political or strategic gain. For example, traditional urban development masquerading as green or ecological restoration.

Legitimacy, Trust, And Fundamental Social-Psychological Needs

Legitimacy

and Trust

Participatory Democracy

Regulatory Systems
Legitimacy and trust are fundamental to effective governance and may help society cope with uncertainty and change during adaptation. Fundamental needs influence perceived legitimacy and trustworthiness of environmental governance. Stakeholder participation in design and/or implementation of environmental governance supports fundamental needs for self-determination (SD) and procedural justice (PJ), but can backfire:

(A): Subjective participation: personal definitions of genuine participation vary across individuals, groups, and contexts. Objective levels of stakeholder involvement do not directly translate into high levels of felt SD or PJ.

(B): Participatory fit: multiple forms of participation may be needed to satisfy different stakeholders. Desirable forms of participation may change over time, during deliberation, planning, implementation, and conflict resolution.

(C): Iterated design: iteratively assess stakeholder needs and perceptions to help identify desirable participatory processes and make necessary adjustments.

Stakeholders need reassurance that they will not be taken advantage of by others and that rules and cooperative agreements will be honored. Regulatory systems (e.g., enforcement, monitoring) help provide this sense of security, but can backfire: poorly designed regulatory systems can be perceived as coercive and undermine more voluntary or intrinsically motivated forms of cooperation.

(A): Legitimization: regulations must be justified and legitimized. Participatory democracy, in which stakeholders contribute to design or implementation of regulations, or have a say (e.g., voting), may help legitimize use of enforcement, safeguarding $\mathrm{SD}, \mathrm{PJ}$, and more voluntary or intrinsic motivations.

(B): Empowerment: regulations should be used to empower stakeholders, not just deter rule violators, helping communities reach their goals and protect chosen rules and agreements. Restorative justice components of regulatory systems like education, open dialogue, justification, and graduated sanctions, which increase with the severity of the violation, may help empower communities.

${ }^{1}$ Primary source: Castro (2012).

The laws themselves are also sometimes designed around faulty mental models. Environmental law in the United States assumes that SESs are simple linear systems, underestimating their dynamism, interconnectedness, and uncertainty (Green et al. 2015). The Adaptive Water Governance Project identified this heuristic mental model as a major barrier to adaptation in many SESs (Ruhl 2011, Cosens et al. 2014a). For example, the U.S. Endangered Species Act requires habitat protection for endangered species, but has been criticized for ignoring broader ecosystem dynamics and other species in the ecosystem. The act has also been criticized for ignoring complex social issues and relationships: for example, species protection (e.g., fish) can sometimes override people's needs (e.g., agricultural irrigation, industry). This issue has caused lawsuits that undermine cooperation and stall multistakeholder negotiations (e.g., b et al. 2014a, Gunderson et al. 2014). Thus, scholars argue that the act leads to piecemeal, maladaptive ecosystem management (Arnold and Gunderson 2013). Some policies lock in solutions indefinitely, explicitly preventing change. The Prior Appropriation Doctrine allocates specific amounts of water to existing users based on historic water conditions. This policy is problematic because climate change has altered historic water patterns, and new 
stakeholders and water uses have entered many watersheds (e.g., Benson et al. 2014). Other policies prevent government agencies from responding to problems in a timely fashion. For example, the U.S federal Administrative Procedures Act and National Environmental Policy Act generally require extensive upfront judicial review, public engagement, and cost-benefit analysis before agencies can test novel solutions to environmental issues (Craig and Ruhl 2014). These policies are based on unrealistic expectations about the level of certainty decision makers can have upfront, about complex SESs (Craig 2010, Sugihara et al. 2012).

Members of the general public, including news reporters and policymakers, also have faulty mental models of SESs that impede adaptation. According to Weber and Stern (2011), people have simplistic models of climate change. Laypersons wrongly equate greenhouse gases like $\mathrm{CO}_{2}$, which contribute to global warming, with air pollutants that quickly disperse without human intervention. Laypersons also confuse localized weather events with climate. For example, some may believe global warming is false because of a recent cold-weather event (e.g., Moskowitz 2014). These misconceptions reduce the perceived need for longterm policy changes and undermine public support (Reynolds et al. 2010).

Additional problems with mental models arise because complex issues can be interpreted or framed in different ways, and these frames can be difficult to reconcile. For example, Arnold (2014) identified 16 ways that watershed systems can be framed in environmental law. Many of these frames contradict one another (e.g., economic highways versus sacred places). This issue is problematic because contradictory watershed frames can increase conflict (e.g., Chaffin et al. 2014b), hinder coordination (Vreudenhill et al. 2010), and stall important decisions at the problem definition stage (Moser and Ekstrom 2010). Therefore, reconciling competing mental models is often a crucial step in adaptive governance (e.g., Arnold 2014, Chaffin et al. 2014b; see Ostrom 2005, Pahl-Wostl 2009 for discussion).

Vreudenhill et al. (2010) illustrated how difficult it is to reconcile mental models. They surveyed professionals involved in a river project on the Netherlands's Waal River, which was tasked to address concerns ranging from flooding, economic vitality, and ecosystem restoration. They found that the professionals (e.g., hydrologists, geologists, planners) had different definitions of what constituted a watershed and different scale preferences for dealing with these problems. For example, some experts defined a watershed strictly in terms of its hydrological characteristics whereas others defined it into terms of its geographic or political characteristics. They could not agree on an ideal scale to work within (e.g., local vs. regional), so they turned to an ambiguous law for guidance. The law stated that landowners are responsible for maintaining discharges to the river. However, the law did not clarify which landowners or their geographic location. They settled on local landowners, because this could be more easily defended and would reduce the number of stakeholders involved, simplifying the problem. However, this decision eliminated superior, less costly, equally effective options further downstream, and it precluded potentially helpful actors from participating, which could cause problems in the future.

Similar problems arise with social-ecological resilience, a foundational concept in adaptive environmental governance
(Chaffin et al. 2014a). Experts disagree about how to define and measure resilience, the relative importance of social issues in resilience, and its ethical or normative implications for society. Many overviews already exist (e.g., Davidson 2010, Cote and Nightingale 2012), so we do not review the debate. However, this problem is important, because it represents another cognitive barrier to adaptive governance (e.g., Gray et al. 2015).

\section{Loss aversion}

Loss aversion is another cognitive bias with potentially farreaching impacts on adaptation. Generally speaking, decision makers are loss averse: they dislike and avoid losses (Tversky and Kahneman 1981, Kahneman 2003). Thus, loss aversion can be a barrier to change when people perceive change as a loss (Kahneman 2003). Unfortunately, many environmentally responsible behaviors seem like a loss simply because they represent a departure from the status quo or involve personal sacrifice (e.g., reducing water use; Winter 2000, Cornforth 2009). Environmental innovations can also be strategically portrayed as a loss for political gain (Weber and Stern 2011). For example, Hardisty et al. (2010) demonstrated that political conservatives in the United States (i.e., Republicans) tend to perceive taxes as a loss. As a result, otherwise identical carbon mitigation policies were viewed less favorably when they were called a carbon tax instead of a carbon offset.

The barriers generated by loss aversion are more systemic than simple framing. Lifestyles and power relationships are deeply entrenched in society. Changes to environmental governance often disrupt existing social structures, so any change in environmental governance risks being seen as a loss of power (Kemp et al. 1998, Cote and Nightingale 2012), thereby increasing resistance to change (e.g., Attari et al. 2009, Lavergne et al. 2010). There are many cases in which government officials deliberately defied laws requiring public participation because they viewed participation as a loss of control (e.g., Arnstein 1969, Castro and Batel 2008, Marshall 2008). This problem occurred frequently in the water basins studied by the Adaptive Water Governance Project and contributed to poor social-ecological outcomes (e.g., Arnold et al. 2014). These examples illustrate that loss aversion affects both government officials and the general public.

Loss aversion is also embedded in legal systems. Specifically, the aforementioned lifestyle losses and losses of power represent endowment effects, in which individuals avoid losing something they possess (Kahneman 2003). Endowments effects are entrenched in United States environmental law to stabilize economies and protect property rights (Doremus 2003, Korobkin 2003). Some of these legal provisions have been identified as barriers to climate change adaptation (Doremus and Hanemann 2007, Craig 2010). For example, as previously described, the U. S. Prior Appropriation Doctrine gives historic water users first priority during water shortages. This provision protects senior claims on water, but also impedes necessary reform and cooperation when new collaborative agreements and more flexible and inclusive water allocations are needed to address climate change (e.g., Huber 2011, Ruhl 2011, Schlager and Heikkila 2011, Arnold and Gunderson 2013, Benson et al. 2014).

\section{Leverage points}

These cognitive biases cannot be solved easily and require more research to address. Therefore, rather than outline specific 
solutions that are unlikely to succeed, we discuss potential concerns with a few of the most prominent solutions seen in the literature.

Individuals and governments often apply rigid and flawed mental models to environmental policies and are averse to changes (losses) in these policies. These biases often operate without conscious awareness and interact with context (Winter 2000, Swim et al. 2011). Unfortunately, many of the solutions proposed by scholars in the cognitive and decision sciences fail to acknowledge the complex nature of SESs and instead emphasize relatively simple solutions based on a few psychological principles (see Poteete et al. 2010, Ostrom 2009 for discussion). Compartmentalizing these problems in that way may not be effective.

\section{Public education and social learning}

Many solutions focus on the informational aspects of the problem (e.g., Cornforth 2009, Weber and Stern 2011). It is assumed that if people were better informed about facts, then they would make better decisions, reconcile their mental models, and work well together (McKenzie-Mohr 2000). Two of the most common examples of this are environmental education campaigns (e.g., Weber and Stern 2011) and social learning (e.g., Ostrom 2005, Beratan 2007), which places diverse stakeholders in direct communication, so that they can learn from one another and develop more trusting, cooperative relationships (Gerlack and Heikkila 2011).

We argue that these solutions are necessary but insufficient. Knowledge is only one part of behavioral change and adaptation. For example, individuals may be knowledgeable, but not motivated to adapt. They may not have sufficient economic, organizational, or legal opportunities to alter their behavior, and adaptation may go against social norms (McKenzie-Mohr 2000, Steg and Vlek 2009, Malone et al. 2013). Education and social learning also pose practical challenges that reduce their effectiveness, such as figuring out how to structure the social learning process and how to properly educate and engage the public (Monroe et al. 2008, Reed 2008, Gerlak and Heikkila 2011, Leach et al. 2013). Information campaigns can also be distorted by powerful stakeholders in society (Weber and Stern 2011).

\section{Strategic framing}

A popular solution for loss aversion is to subtly adjust default policy options and organizational settings toward more ecologically responsible defaults (Gattig and Hendrickx 2007, Cornforth 2009). People tend to stick with default option settings because of loss aversion, status quo bias, and other reasons. Changing these defaults to be more ecologically friendly could use people's natural inclination for loss aversion to societal advantage, e.g., default thermostat settings, default social policies (Thaler and Sustein 2008). Information could also be reframed to mask potential losses and emphasize other dimensions of the issue, potentially reducing loss aversion, e.g., portraying carbon taxes as carbon offsets (Hardisty et al. 2009).

These strategies may help. However, recent research indicates that defaults tend to be scrutinized in broader public discourse and are resisted as secretive, manipulative, and circumventing legitimate democratic processes, undermining trust and cooperation (e.g., Yee 2012; see Leonard 2008, Jung and Mellers
2016 for review). One way to counteract this issue may be to frankly communicate the need for new defaults, however challenging that may be (Moller et al. 2006). As previously described, loss aversion is also incorporated into environmental law (Doremus and Hanemann 2007). Reframing will not help these structural manifestations of loss aversion; they must be addressed with changes to the legal system itself (Craig 2010, Huber 2011, Kosters and Van der Heijden 2015).

Thus, rigid mental models and loss aversion may be addressed with strategies targeting knowledge change, framing, and change in defaults. However, structural issues, and the potential for these strategies to be undermined, limit their effectiveness in isolation. Many of the problems outlined are amplified by shortcomings in social cognition. Thus, scholars of adaptive governance need to also consider how social cognitive biases influence societal cooperation and receptiveness to adaptation.

\section{SOCIAL COGNITIVE BIASES}

The outlined cognitive biases increase people's susceptibility to certain social cognitive biases (Table 1). These biases can undermine cooperation and increase conflict over proposed changes to environmental governance systems. Many of these biases are preyed upon by powerful stakeholders in society and amplified by social systems, reinforcing their detrimental effects on adaptation.

\section{Social framing effects}

Weber and Stern (2011) described how people's cognitive limitations cause them to take social cognitive shortcuts that make it easier for them to be influenced by interest groups who oppose adaptive environmental governance, using strategic social frames. We extend that description by incorporating broader lessons from social cognition.

At least three aspects of social cognition increase susceptibility to social framing. These mechanisms reinforce one another.

1. To save time and cognitive resources, people look to their accepted social groups for important information (Long 1958, Levine 1999). For instance, laypersons rely on popular media coverage and respected figureheads in their ideological community (e.g., family, religious leaders, politicians) to understand climate change (Weber 2010). Unfortunately, these sources are often not scientific experts, and they may be motivated to resist climate change policy for political reasons (McCright et al. 2014).

2. People feel threatened by information that contradicts their worldview (Winter 2000), and they ignore or devalue perspectives that contradict their beliefs (Nickerson 1998). They also seek out similar others (in-groups) who share their beliefs, further insulating and reinforcing those beliefs (Abrams et al. 1990, Wood et al. 1996). Thus, erroneous mental models are socially reinforced and difficult to change (Stern and Easterling 1999, Sunstein 2000).

3. Laypeople use cognitive shortcuts to understand probabilities, such as the perceived likelihood that an environmental catastrophe is imminent. These subjective probability estimates are easily distorted by extraneous information, like the emotional labels used to describe important events and how often they are discussed in the 
media (Lichtenstein et al. 1978, Loewenstein et al. 2001, Kahneman 2003). For example, imbalanced coverage of fringe scientific beliefs can distort public perceptions of environmental trends, like the cause and effects of climate change (Weber and Stern 2011).

\section{Climate change framing}

As just one example, climate change can be strategically framed to evoke an emotional response and to distort facts for political purposes, discouraging societal support for adaptive environmental policies. According to a review by Weber and Stern (2011), when news outlets cover climate change, they focus on controversial issues and provocative events. They also use emotional labels and feature fringe guests who have extreme beliefs to increase their viewership and attempt to show all sides of an argument (see also Boykoff and Boykoff 2004). As a result, important issues are presented in emotional terms with a disproportionate emphasis on climate change skepticism.

U.S. news media inadvertently give interest groups who oppose new environmental policies an ideal platform to undermine societal cooperation (Lever-Tracy 2010, Farrell 2016). For example, conservative political leaders routinely frame environmental policies negatively, preying on the public's cognitive biases. They pit environmental responsibility against economic security, strategically portraying climate change adaptation as a loss, for example: sustainability versus jobs (Schlichting 2013). They use emotional labels like "the war on coal" (McGinley 2011, Smith 2012) to frighten and anger their social supporters, strategically mobilizing them against climate change policy (see Edelman 1960, Bauer and Gaskell 2008 generally).

Popular misconceptions about climate change spread by the media and further amplified by people's social networks have polarized U.S. environmental politics (Weber and Stern 2011, McCright et al. 2014). According to Gallup polls, the public generally agreed with the scientific community's concern for climate change in 1997 but began to diverge along conservative versus liberal political party lines in 2001, creating a large bipartisan gap (Dunlap and McCright 2010). This pattern coincides with documented political lobbying and financial support from opposition leaders in major oil and gas companies, religious groups, and powerful conservatives (Schlichting 2013, Stoknes 2014, Farrell 2016). Hence, political affiliation (in-group bias) now reliably predicts support for environmental policy innovation (e.g., Gromet et al. 2013).

\section{Social representations}

Similar to framing effects, Castro (2012) described several specific social representations (Moscovici 1988), or societal interpretations of environmental law, that people commonly use to subtly undercut legal innovations in environmental governance.

For example, people can agree with legal innovations in principle but disagree with concrete instances of their application (agreeing in principle). This behavior allows actors to simultaneously support legal innovations they ultimately oppose, disguising their noncompliance. Landowners often agree with protecting biodiversity (e.g., Endangered Species Act), but object to having restrictions on their own land (Opotow and Brook 2003, Castro and Mouro 2011). Castro and Batel (2008) described how government officials in Lisbon used this strategy to circumvent a UN directive to involve the public in urban planning projects. They agreed with democratic participation in principle but argued that their citizens were not knowledgeable, interested, or democratic enough to participate.

Legal innovation can also be undercut by equivocation (Castro 2012). For example, because the UN Directive did not clarify "adequate participation," Lisbon government officials were able to use very minimal forms of public engagement (e.g., public hearings), which maintained their decision-making control, and say that they satisfied the directive (Castro and Batel 2008). This type of rationalization occurs frequently in environmental governance (e.g., Clement 2010, National Civic League 2013) and is a common barrier to public participation in adaptive water governance (e.g., Arnold et al. 2014, DeCaro et al. 2017), as previously noted in our discussion of government reliance on centralization and principles of rational choice theory (Marshall 2008, Ostrom 2010).

\section{Symbolic policy}

Another social cognitive barrier to adaptive governance is symbolic policy activity. Symbolic policies often arise because of competition among interest groups for political influence and economic resources (Edelman 1960, 1985, Meyer and Rowan 1977). These symbolic policies are designed to improve one's public image and mobilize constituents, without making substantive policy contributions. For example, many governmental and commercial actors in the U.S. National Estuary Program symbolically participate in collaborative programs, without making any substantive contribution to policy or adaptive ecosystem management (see also Lubell et al. 2010, Westphal and Zajac 2013). Similarly, many U.S. municipalities join climate protection networks and espouse goals to reduce greenhouse gas emissions, but few implement actual policies (Krause 2011). Symbolic policy was also identified as a problem by environmental groups in the U.S.'s Anacostia River system, which claimed that several green urban development projects (e.g., a LEED certified sports stadium) were merely symbolic gestures (Arnold et al. 2014).

\section{Leverage points}

Some social scientists have suggested using social framing effects to societal advantage by portraying environmental policies and governance systems in ways that will mobilize stakeholder groups to support adaptation (e.g., Thaler and Sustein 2008, Cornforth 2009). However, strategic social framing appears to be unreliable by itself. This approach is backfiring in U.S. discourse, for example, regarding climate change policy. Both sides of the argument in U. $\mathrm{S}$. politics have been engaging in social framing for decades, and the general public is more polarized than ever (Dunlap and McCright 2010). Political posturing can undermine credibility and trust, and enflame conflict (Jung and Mellers 2016), undermining cooperation (Tyler 2006). More specifically, social representations are inherent to social discourse (Levine 1999), so social frames are always open to counter debate and reframing (Castro 2012).

Symbolic policy is an impediment to real change in adaptive governance and should be avoided (e.g., Lubell 2004, Lubell et al. 2010, Arnold et al. 2014). However, most policy activity is nuanced, involving both genuine and symbolic elements. It is important to recognize this contingency. For example, ecological restoration projects are sometimes used both to build symbolic support and improve ecosystems (Berrone et al. 2009, Kim and Lyon 2013). In 
addition, cooperative activities that seem symbolic can actually yield important indirect social benefits like trust, acceptance, and social learning (e.g., Leach et al. 2013). Trust can smooth policy deliberations, helping parties endure contentious negotiations long enough to reach tangible agreements that improve ecological conditions (Leach and Sabatier 2005, Chaffin et al. 2014b; see Kenney 2000 for discussion). Finally, novel solutions can take decades to produce tangible results (e.g., Birgé et al. 2014, Chaffin et al. 2014b).

People desire fairness, transparency, and consistency from government, especially on issues of conflict and uncertainty (Tyler 2006). Therefore, regardless of how treacherous it may seem, there may be no substitute for genuine public discourse and open communication about proposed legal innovations and other solutions. Public discourse may be especially necessary if society values democracy and cooperative problem solving(Ostrom 1971, Shivakumar 2005), or regards democracy and cooperation as essential elements of adaptive governance (Dietz et al. 2003, PahlWostl 2009).

\section{LEGITIMACY, TRUST, AND FUNDAMENTAL SOCIAL- PSYCHOLOGICAL NEEDS}

Legitimacy plays a central role in governance. A government or social policy that is viewed as legitimate builds trust, facilitates cooperation and rule compliance, and helps smooth contested social dilemmas (DeCremer and Tyler 2005, Tyler 2006). For example, Tyler and Degoey (1995) found that perceived legitimacy and trust in government officials predicted compliance with water conservation restrictions in California, USA during a drought. Similarly, Leach and Sabatier (2005) reported that perceived legitimacy and trust smoothed negotiations concerning a contentious water policy, improving policy outcomes (see also Syme et al. 1999).

Legitimacy and trust may be especially important for adaptive governance (Ostrom 1998, Cosens 2013). Trust helps society endure contentious and uncertain situations, and people look to legitimate governance systems for reassurance during crisis and transformation (Tyler 2006). Legitimacy helps people cope with stressors during adaptation, maintaining a sense of order and stability amid change (Craig et al. 2017, see also Lind and van den Bos 2002).

Participatory and regulatory aspects of governance, like voting, deliberation, monitoring, and enforcement, influence perceptions of legitimacy and subsequent cooperation (Tyler 1990, 2006, Ostrom 1998, DeCaro et al. 2015). However, these features are complex and can easily backfire (e.g., Bowles 2008, Reed 2008). Careful consideration of fundamental needs can help clarify when and why governance interventions backfire, potentially improving institutional design (Tyler 1990, Frey et al. 2004, Moller et al. 2006). We describe the relationship among legitimacy, trust, and fundamental needs to demonstrate important motivational constraints on participatory and regulatory mechanisms, which may affect the legitimacy and acceptance of adaptive environmental governance systems.

\section{Procedural justice, self-determination, and security}

Fundamental social-psychological needs for procedural justice (Tyler 2006), self-determination (Moller et al. 2006), and security (Hobbes 1651/1909, Ostrom 1998) strongly influence legitimacy, trust, and cooperation. These fundamental needs represent core dimensions of human governance and are central drivers of human motivation and decision making (Deci and Ryan 1987, 2000, Tyler 2006, van Prooijen 2009, Leotti et al. 2010).

Procedural justice is the perception that decision-making procedures are fair and support one's political voice or decisionmaking control (Tyler 2006, Colquitt 2001). Self-determination refers to being able to pursue goals in ways that align with one's core values and support one's sense of agency (Ryan and Deci 2006). Security refers to predictability and orderliness (Sheldon et al. 2001), which is necessary for long-term planning and coordination (Ostrom 1990, Craig et al. 2017). Security also influences commitment, because people often do not want to obey rules or cooperate with others when they think others can exploit them or disobey rules with impunity (Hardin 1968, Ostrom 1990, Milinski and Semmann 2002).

When governance systems satisfy these fundamental needs, perceptions of legitimacy and subsequent trust, social acceptance, and internalized motivation tend to increase (Tyler 2006, Frey et al. 2004, Deci and Ryan 1987, 2000). Internalized motivation and social acceptance are important because they promote voluntary compliance and more sustainable cooperation (Pelletier 2002, DeCaro et al. 2015).

\section{Participatory democracy}

Participatory democracy (participation) is fundamental to legitimacy (Tyler 2006) and may be essential to adaptive environmental governance (von Korff et al. 2010, Cosens 2013). Participatory practices include stakeholders in the feedback, design, decision making, or implementation of governance systems. Participation can promote cooperation and improve ecological outcomes by satisfying fundamental needs for procedural justice and self-determination, which encourage policy acceptance and internalized motivation (e.g., Leach and Sabatier 2005, Lavergne et al. 2010, McComas et al. 2011; see Frey et al. 2004, DeCaro and Stokes 2008, 2013 for review). When properly implemented, participation can also facilitate social learning (Pahl-Wostl 2009, Leach et al. 2013), diversity (Reed 2008, Huitema et al. 2009), and social-ecological fit (DeCaro and Stokes 2013), which are major components of adaptive governance systems (Marshall 2008, Ruhl 2011). Participatory processes can also increase transparency and accountability, improving security, compliance, and environmental justice (Ostrom 1990, Bullard and Johnson 2000). Clear communication, combined with fair and transparent participation in governance, can reassure societal stakeholders during difficult times and help build a sense of security and trust needed to cope with change constructively (e.g., Tyler 2006, McComas et al. 2011, Cosens 2013, Craig et al. 2017).

However, participation can also backfire, reinforcing power inequities in society and generally undermining the potential benefits through misapplication (e.g., Chess and Purcell 1999, Irvin and Stansbury 2004, Turnhout et al. 2010) and outright manipulation (e.g., Arnstein 1969, Clement 2010). Some of these problems occur because participatory processes are extremely complex (Fung 2006, Margerum 2008). Designing and properly implementing participatory processes is not a simple task (Chess and Purcell 1999, van Korff et al. 2010). Many factors affect participatory democracy (Reed 2008), including social cognitive constraints. 
DeCaro and Stokes $(2008,2013)$ reviewed case studies of environmental governance from the standpoint of fundamental needs, legitimacy, and cooperation. They demonstrated that government officials and scholars underestimate the social cognitive complexities involved in participation, contributing to its misapplication. For example, there is a popular misconception that specific types of participation (e.g., deliberative democracy) are superior and generate the same perceptions of procedural justice and self-determination regardless of culture or context (e.g., Arnstein 1969, Hunt and Haider 2001). This misconception results in overly simple solutions and over application of specific solutions (Ostrom 2009, Adams and Hulme 2001), which ultimately undermines legitimacy (DeCaro and Stokes 2013). Some government officials fear losing control (Bailey and Grossardt 2010). Other officials believe that participatory processes are all interchangeable (e.g., Castro and Batel 2008), ignoring their essential differences (Reed 2008). This inaccuracy leads to superficial participation and exploitation (e.g., National Civic League 2013).

The U.S. administrative legal system was reformed to correct serious shortcomings in participatory democracy (Arstein 1969, Bingham et al. 2005), including environmental injustice (Bullard and Johnson 2000, Cosens 2013). However, these problems still largely exist because they are systemic. Structural inequities and popular misconceptions about participation are built into governance systems and implemented in everyday practice (e.g. Arnold 2004, Shilling et al. 2009, National Civic League 2013). Problems with participatory democracy were major barriers to adaptive governance and positive ecological outcomes in every basin studied by the Adaptive Water Governance Project, such as the Anacostia (Arnold et al. 2014), Columbia (Cosens and Fremier 2014), and Klamath (Chaffin et al. 2014b).

\section{Leverage points}

Several aspects of participation influence subjective perceptions of procedural justice and self-determination, such as transparency, neutrality (nonbias), timeliness, honesty, voice and choice or "inclusiveness," rationales, and opportunity for appeal or "accountability" (Tyler 1988, Lawrence et al. 1997, Moller et al. 2006). These factors can interact, are affected by context, and may change throughout the life of a social-ecological dilemma (e.g., Howard 2010). Therefore, we recommend that government officials and scholars take an adaptive approach to both the design and study of participatory processes (von Korff et al. 2010, Munarreto et al. 2014). This approach should include assessments of socialecological conditions and perceptions to guide adaptation and ensure proper fit (DeCaro and Stokes 2013).

For example, Turner et al. (2014) interviewed approximately 70 households from 12 reef-dependent communities in the Caribbean. They found that perceptions of legitimacy, inclusiveness, accountability, and other factors (e.g., fair enforcement) differed across communities based on specific elements of participatory democracy, enforcement, planning, and decision making. These differences highlighted potential areas for improvement for specific communities, like increased devolution of control and involvement of NGOs to facilitate collaborations (see also, Sarkki et al. 2015). Additional improvements may be identified by assessing stakeholder perceptions and preferences for particular types of participation (e.g., Chase et al. 2002, Luyet et al. 2012, Druschke and Hychka 2015; see DeCaro and Stokes 2013 for review). It may be necessary to use multiple types of participation to satisfy different stakeholders and address new needs that arise during different stages of participation. Planning and design pose different participatory challenges than implementation and conflict resolution for instance (Howard 2010, von Korff et al. 2010).

Some legal scholars have started to envision legal frameworks to improve participatory processes and facilitate adaptive governance. Cosens (2013) discusses principles of legitimacy in U.S. administrative law, suggesting that government agencies seek to increase their (1) evidence-based legitimacy, by basing decisions on sound science, (2) order-based legitimacy, by increasing transparency, (3) systemic legitimacy, by creating reasonable checks and balances among government agencies and procedures, and (4) procedural legitimacy, by increasing public participation and communication (see also Esty 2006).

Bingham $(2009,2010)$ and the National Civic League have drafted proposed amendments to the U.S. Administrative Procedures Act and city charters, which may address order, systemic, and procedural aspects of legitimacy. Specifically, the amendments (1) broaden and clarify what constitutes adequate participation and (2) create an official liaison to facilitate public participation and train government employees. These provisions may prevent and correct many of the problems we have identified with ambiguity and superficial participation.

Craig and Ruhl (2014) also outlined amendments to the U.S. Administrative Procedures Act. Their amendments give government agencies more flexibility to make adaptive decisions, without sacrificing public engagement. If these amendments are combined with Bingham's $(2009,2010)$ amendments, they may reduce agency fear of public involvement, encouraging better public engagement. Specifically, instead of undergoing constant external judicial review and public scrutiny, which has been identified as a barrier to agency experimentation and adaptation (e.g., Gunderson et al. 2014), agencies would be reviewed periodically (e.g., every three to five years), giving them time to test different solutions and develop better understanding of complex problems. Similar solutions emerged in some U.S. watersheds (e.g., Columbia River, Cosens and Fremier 2014) and community-based governance systems with overall positive outcomes (e.g., Ostrom 1990, 2014), providing preliminary support for this approach.

\section{Regulatory systems}

Regulatory systems (e.g., monitoring, enforcement) are commonly used to ensure security and encourage cooperation (Hardin 1968, Rachlinski 1999). Credible safeguards against uncooperative behavior are needed to protect conservation agreements and enforce rules (Hardin 1968). Enforcement can facilitate trust (Ostrom 1990, 1998) and increase rule compliance, by deterring defectors and creating a safer, more secure environment for cooperators to thrive, without being exploited by others (Yamagishi 1986, Gächter 2007, Rustagi et al. 2010). Effective and appropriate enforcement can, therefore, increase the perceived legitimacy of governance systems (Tyler 1990, 2006). Indeed, most environmental governance systems have some kind of regulatory system to encourage cooperation (e.g., Cox et al. 2010, Heikkila et al. 2011, Sutinen and Kuperan 1999). Hence, 
regulatory activities, like monitoring and enforcement (e.g., financial penalties), are fundamental aspects of environmental governance and are important to adaptive governance (Dietz et al. 2003, Marshall 2008).

However, regulatory systems can also backfire. Regulatory systems can increase conflict and decrease cooperation (e.g., Peluso 1993), if they are perceived as coercive, improper, or unfair (Tyler 1990). Regulations can also decrease intrinsic, voluntary forms of cooperation that are essential to long-term environmental governance (Bowles 2008, Frey et al. 2004). Voluntary motivations for cooperating, like moral obligation and belief in the inherent importance of an environmental policy, are important because it is not possible to perfectly monitor resource systems or enforce environmental policies (Sutinen and Kuperan 1999). Moreover, complex social-ecological dilemmas often require some voluntary effort for stakeholders to overcome setbacks, solve emergent problems, and persist despite personal cost (DeCaro and Stokes 2008, Ostrom 2000, 2014).

Several psychological processes may be involved when regulations are counterproductive (Bowles 2008, DeCaro et al. 2015). Regulatory systems can: (1) signal distrust encouraging stakeholders to behave uncooperatively (Mulder et al. 2006); (2) reframe formerly moral obligations (doing what is right) as economic transactions, making more voluntary ethical behavior optional, or seem like a purchasable service (Tenbrunsel and Messick 1999); (3) make stakeholders dependent on enforcement by convincing them that others are cooperating only because they fear punishment (Chen et al. 2009); and (4) undermine selfdetermination, creating active resistance and reducing intrinsic motivation (Brehm and Brehm 1981, Moller et al. 2006).

\section{Leverage points}

The primary behavioral challenge in designing regulatory systems is to discourage defectors without undermining more internal motivations, or increasing conflict (Bowles 2008). It is therefore important to ensure security without threatening fundamental needs for procedural justice and self-determination (DeCaro et al. 2015). One way to do this is to allow stakeholders to participate in the design of rules and their enforcement. Doing so helps to justify or legitimize regulatory systems (Tyler 1990, 2006), preserving underlying fundamental needs and cooperative motivations (see DeCaro et al. 2015 for review).

For example, in an experimental test, DeCaro et al. (2015) found that monitoring and enforcement (i.e., economic fines) had different effects on cooperative motivations and performance, depending on whether groups voted on conservation rules (votedenforce group), or had the same rules imposed on them without a vote (imposed-enforce group). In particular, compared to groups that had rules imposed on them, groups that voted and could enforce had higher perceptions of procedural justice and self-determination, security, group cohesion, rule acceptance, and internalized motivation. The voted-enforce group also cooperated better and conserved a limited resource longer, even after enforcement was later removed (see Epstein 2017 for a replication study involving 93 real-world forest user groups).

Similarly, many case studies (e.g., Ostrom 1990, Cox et al. 2010) and experiments (e.g., Tyran and Feld 2006, Markussen et al. 2014, Hilbe et al. 2014) find that enforcement is more effective when chosen by election and participatory design, than when imposed. Sinner and Salmon (2003) described a case (Convery and McDonnell 2003) in which the Irish Government sought to introduce a levy on plastic bags to improve natural scenic conditions and support ecotourism. Some storeowners initially opposed the levy, because they feared it would overburden customers and be perceived as distasteful. Government responded by consulting storeowners, revising the policy (e.g., to include exceptions for particular goods), and educating the general public on rationales for the levy. These steps increased policy acceptance and subsequent cooperation for the levy, and they reflect several dimensions of procedural justice and self-determination (Lawrence et al. 1997, Moller et al. 2006). An analogous policy situation is currently underway in the U.S. Anacostia River (Brittain and Rich 2015).

DeCaro et al. (2015) also proposed that regulatory systems be used to empower stakeholders by helping them reach shared goals and not simply to force compliance. Specifically, their results suggested that having the ability to enforce rules that were chosen by the group was empowering, whereas enforcing rules that were imposed externally seemed unjustified and illegitimate, or oppressive (see also Tyler 1990). Ostrom (1990, 2000) further argued that effective regulatory systems incorporate components of restorative justice, which educate and rehabilitate rule violators, helping build community and develop trust (see also van Ness et al. 2013).

Supporting this idea, Ostrom's (1990, 2010) analysis of community-based governance systems demonstrates that effective regulatory systems often co-occur with participatory processes and are rarely introduced without endorsement by the governed (see also Cox et al. 2010). They also used graduated sanctioning systems, in which punishments increased in severity with each violation, beginning with a warning, education, and open dialogue (see also, Dollar and Ray 2015). Similar approaches have been successful at larger scales, for example, with river compacts and treaties (Schlager et al. 2012) and complex polycentric irrigation networks spanning local, regional, and national governance (Sarker 2013).

After analyzing interstate river compacts in Western U.S. basins, Schlager and Heikkilla (2011) concluded that state governments need to be proactive in supporting multistakeholder decision making, monitoring, and enforcement, to increase cooperation and compliance. Furthermore, more effective conflict resolution mechanisms are needed to mitigate serious disputes and maintain cooperative ties (see also Ostrom 1965, 1994). Stakeholders in interstate water agreements may resolve disputes more cooperatively when there are voluntary mechanisms for conflict resolution, in addition to courts (Leach and Sabatier 2005, Schlager et al. 2012).

The examples illustrate that fundamental needs play a pivotal role in effective participatory and regulatory processes underlying adaptive governance. These examples also highlight the importance of social cognitive constraints, such as legitimacy, on democratic decision making and enforcement. Laws targeting participatory democracy and enforcement must be based on sound principles of social cognition and governance, to ensure they accomplish their intended aims of facilitating adaptive governance. 


\section{BROADER LEVERAGE POINTS}

Our primary goal in this literature review is to raise awareness of important cognitive and social cognitive factors of decision making that shape adaptive environmental governance. Legal scholars and policymakers should be aware of these factors, so they can consider ways to address them in legal and institutional design. Knowledge of these factors is also useful for research to describe potentially crucial behavioral influences on adaptive governance. We discuss four topics that may be essential starting points for improved adaptive environmental governance. These topics are not exhaustive (see Moser and Ekstrom 2010). However, they are highly relevant to our emphasis on social cognition and societal cooperation.

\section{Future research}

We discussed several cognitive biases and social cognitive processes that seem to fundamentally influence societal capacity for cooperation and adaptation (Table 1). Briefly, limitations in human cognition create informational, motivational, and decisionmaking barriers to adaptive problem solving and governance, which may lead to suboptimal solutions and slow necessary change. These cognitive limitations are amplified by public discourse (e.g., political framing, news), increasing susceptibility to certain social cognitive biases that enflame conflict, decrease acceptance of legal and institutional innovations, and undermine societal cooperation.

What design features might alleviate these problems? Simple solutions are unlikely to adequately address the complex social, behavioral decision making, and legal problems identified in this review. Moreover, simple solutions generally cannot properly anticipate the context-dependent nature of most social-ecological dilemmas. Hence, we join other scholars in warning against overly simple, one-size-fits-all solutions (Ostrom 2007, Epstein et al. 2015). We are also reluctant to offer definitive solutions to the problems raised in this review, because more research is needed to understand the social cognitive processes involved in adaptation.

Scholars should investigate the topics we raised specifically from the perspective of legal innovation and adaptive governance (Table 1). We have already discussed potential starting points in the Leverage points sections. Many of these principles and topics represent active areas of investigation, but typically not from the standpoint of understanding legal and institutional foundations of adaptive governance. For example, scholars may wish to explore such questions as: how is a focal issue being framed by different groups, and how are those frames influencing conflict, cooperation, and change (e.g., Castro 2012, Arnold 2014)? What role have perceptions of regulatory systems and participatory processes played for different groups, issues, or social-ecological settings (e.g., DeCaro and Stokes 2013)? What factors have contributed to the perceived legitimacy or illegitimacy of particular adaptive processes among particular stakeholders (e.g., Kubo and Supriyanto 2010, Druschke and Hychka 2015)? How has each of these processes interacted with specific legal systems and situations?

We are not aware of any studies that integrate the principles we reviewed or comprehensively examine their contribution to adaptive governance. Thus, one of our goals is to encourage scholarly integration. It is unclear how these principles operate in particular social-ecological contexts, or how they interact with one another to influence important outcomes. Hence, more integrative researched is needed.

Research integration: stages of legal innovation framework The stages of legal innovation concept developed by Castro and colleagues could provide a useful framework for scholarly integration. According to Castro (2006, 2012) and colleagues (Castro et al. 2009), legal innovations are incorporated into the existing fabric of society through a nonlinear and socially contested process of emergence, institutionalization, generalization, and stabilization. This process is similar to an adaptive governance cycle in resilience theory (see Chaffin and Gunderson 2016). The framework describes how legal innovations in environmental governance are subjectively reinterpreted by society, significantly altering their nature and eventual effects. It may be useful to consider how the principles we identified (Table 1) contribute to each stage of legal innovation.

During emergence, an innovative legal concept, or policy issue, is introduced by a stakeholder group to address a perceived shortcoming in the existing legal framework. The group proposes solutions, which then enter public discourse. These solutions are debated by different interest groups who compete to reframe the topics, altering their meaning and trajectory (Castro 2012). Hence, climate change policy may be strategically framed and reframed by opposing interest groups, altering public discourse and law. Principles such as mental models, loss aversion, and social framing may play a central role in this process, determining the narrative that surrounds emergence (e.g., Dunlap and McCright 2010).

During institutionalization, some interpretations of the legal innovation may be "translated into a set of legal, policy, and institutional changes" (Castro 2012:108). New government agencies, partnerships, or procedures may be created to implement the changes (Castro 2012). It would be important to investigate how the psychological processes and narratives that emerged in early stages of development influenced which governance solutions were institutionalized. It is also important to study how the participatory processes and regulatory systems, which were used to decide and implement these changes, influence their perceived legitimacy, acceptance, and subsequent cooperation (Cosens 2013, DeCaro et al. 2015).

During generalization, proponents of these changes try to encourage widespread adoption, and official governance systems and processes change to accommodate the reforms. However, more informal social, organizational, and institutional norms often remain unchanged, creating a practical barrier to adaptation. For example, as previously described, government officials may resist legal reforms requiring increased public engagement (e.g., Castro and Batel 2008) or fail to enforce policies that are difficult to implement (e.g., Siddiki et al. 2012). The general public may simply not comply with new policies, or may oppose change outright (Gifford 2011). In addition to the principles outlined in Table 1, principles of public engagement (McComas et al. 2011), organizational change (Malone et al. 2013), and social norms and normative influence (Bator and Cialdini 2000, Cialdini 2003), may be particularly relevant during this stage (see Kollmus and Agyeman 2002, Kinzig et al. 2013 for review). 
Finally, during stabilization, these legal changes may be sufficiently entrenched in society's norms and governance systems to become common knowledge and practice. However, they will continue to be contested by certain groups and remain open to reframing and re-emergence. These processes are also open to investigation from an integrative standpoint.

\section{Integrative case studies}

To better understand underlying cognitive and social cognitive decision-making factors involved in adaptive governance, we propose that scholars use Castro's $(2006,2012)$ stages of legal innovation framework to guide their case studies. For example, scholars in the Adaptive Water Governance Project (Cosens et al. 2014a) could revisit their cases to investigate how cooperation and adaptation may have been influenced by each of the principles discussed (Table 1). We suggest that scholars focus on the pivotal events in each basin, highlighting particularly crucial turning points and their potential social cognitive factors. Future research can also consider how the three cooperative themes we identified are impacted: social acceptance, collaborative problem-solving, and societal tolerance for change. Such an approach would clarify the social dynamics of adaptation and generate integrative hypotheses for future research.

For example, the Florida Everglades have seen decades of litigation over who is responsible for past mistakes and who has legal jurisdiction to manage the system, i.e., federal or state government. This litigation has undermined broad-scale cooperation and hindered experimental approaches to ecosystem management. This stagnation is partially caused by excessive external judicial and public review required by statutes like the $\mathrm{U}$. S. Administrative Procedures Act and National Environmental Policy Act (Gunderson et al. 2014). The conflict could be reassessed from a social cognitive decision-making perspective, identifying mental models, social frames, issues of participatory democracy and regulation, and other factors that may be responsible for such sustained cooperative failure. It would also be informative to contrast cases like this one with instances in which stakeholders were more cooperative.

In the Klamath River basin (Chaffin et al. 2014b), several years of litigation and negotiations ensued over changing historic water user rights to adapt to climate change. However, after experiencing years of prolonged cooperative failure, some of the embattled stakeholders decided to communicate about the dilemma more broadly, discussing goals and potential areas of common ground to manage the basin cooperatively (Settlement Group). In 2010, the group drafted a Klamath Basin Restoration Agreement to improve cooperation, reallocate scarce water resources, and restore river habitat for protected species. During this process, groups engaged in social representations, contesting and renegotiating the meaning and function of the existing laws and current governance systems; they also protested restrictive participatory processes, seeking more inclusive, subjectively fair ways to influence critical decisions (see Ostrom 1965, Arnold 2014 for analogous cases). These processes are still unfolding, and the future of governance in the Klamath is still unknown (Chaffin et al. 2014b). However, by studying these kinds of processes as they unfold, we may develop a better understanding of the bridges and barriers that influence societal cooperation and adaptive governance.
In-depth social cognitive analysis, using stakeholder interviews and surveys, could help clarify how these processes unfold (e.g., Kubo and Supriyanto 2010, McComas et al. 2011, Castro 2012, Turner et al. 2014). For example, why did the Settlement Group choose to cooperate despite substantial legal barriers and social conflict, which were also faced in the Florida Everglades? It would also be useful to assess how perceptions of procedural justice, selfdetermination, and legitimacy influenced the creation of potentially transformative agreements, like the 2010 Klamath River Restoration Agreement (e.g., Leach and Sabatier 2005, DeCaro and Stokes 2013).

\section{Social policy experiments}

Each of the principles discussed poses unique barriers to adaptive governance. These principles also have context-specific aspects, which will require additional scientific understanding and on-theground practical experimentation to fully understand. Thus, rather than propose prespecified solutions that are likely to fail out of context, we advocate for more rigorous social policy experimentation (see also, McKenzie-Mohr 2000, Moser and Ekstrom 2010). Craig and Ruhl's (2014) model amendments to U. S. federal Administrative Procedures Act are one example. These amendments give government agencies more authority to test alternative ecosystem management approaches. However, experimentation needs to be much broader.

In the United States, President Obama issued an Executive Order (White House, Office of the Press Secretary 2015) establishing a Social and Behavioral Science Team to study behavioral foundations of public policy. In addition, some municipalities and regional governments have adopted McKenzie-Mohr's (2000, 2013) community-based social marketing (CBSM) approach to test new environmental policies, with positive environmental outcomes (e.g., Sinner and Salmon 2003, Felson and Pickett 2005). In CBSM, policymakers and scientists identify specific behaviors to promote or discourage and then research key cognitive and social cognitive decision-making barriers. Afterward, they design preliminary solutions and pilot test these at smaller scales. Finally, they revise and generalize the solutions to broader scales, with continued assessment.

These approaches seem synonymous with adaptive governance (Chaffin et al. 2014a) and should probably become the norm for both societal problem solving (Fairweather and Davidson 1986) and water governance (von Korff et al. 2010, Pahl-Wostl et al. 2010, Cookey et al. 2016).

\section{Civic education, leadership, and media}

Leadership is also vital for adaptation (Westley et al. 2011, 2013). We encourage formal governments, professional societies, and leaders in the general public (e.g., grassroots organizations) to engage in more direct and frank public education and advocacy. Members of society must be knowledgeable about adaptive governance: what it is, why it is necessary, and its challenges. Such education will enable individuals to (1) better tolerate the uncertainty and conflict associated with adaptation and (2) constructively participate in adaptive governance. Failure to sufficiently grasp the core principles of adaptive governance (e.g., complexity, uncertainty, self-organization, and cooperative problem-solving) may be the single most important psychological barrier to adaptive governance (e.g., (Ostrom 1998, Shivakumar 2005, Chokshi 2016). 
O'Leary et al. (2010) and Ostrom (1998) argued that to adequately prepare society for adaptive governance, civic education must include robust philosophical and practical training in the many ways that societal stakeholders can participate in governance, such as community-based governance (Ostrom 1990, 2010), quasilegislative and -judicial systems (Bingham et al. 2005), tactical demonstrations (Lydon et al. 2010), and collaboration (e.g., Bingham 2009, 2010).

It may also be important for members of the public to become aware of their own cognitive and social cognitive decision-making limitations. Widespread education in cognitive science and social psychology, as well as cooperative decision making (i.e., social dilemmas), may be a crucial precondition for societal cooperation. It is difficult to envision how society can work together to solve complex problems, without basic knowledge of human behavior (Gifford 2011) or the decision-making flaws that contribute to those problems (Cornforth 2009).

\section{Good governance and news media}

Distrust of environmental science and governance has grown among influential groups (Bauer and Gaskell 2008, Weber and Stern 2011, Chokshi 2016). This distrust is partly caused by clear violations of authority, honesty, fairness, and rule of law (e.g., Arnstein 1969, Bullard and Johnson 2000, Clement 2010). News media has also played a role by featuring provocative stories to increase ratings and popularizing misinformation (Weber and Stern 2011).

There may be no substitute for good governance, i.e., legitimacy, transparency, accountability, inclusiveness, and fairness (Chaffin et al. 2014a), to restore trust in government and create a social climate supportive of adaptation (Lockwood 2010, Cosens 2013). Governments and scientific and professional societies need to frankly communicate the rationales and supporting evidence behind their decisions. These decisions should not be made unilaterally (Reed 2008). The Society for Psychological Study of Social Issues (SPSSI) provides a potential model for better scientific advocacy. The SPSSI trains scientists to communicate research to the general public and policymakers; SPSSI also directly advocates for scientifically informed policy change (e.g., U.S. Civil Rights Movement; Dingfelder 2004). In addition, popular news organizations must recognize their role in perpetuating misconceptions that can harm society and adopt precautionary methods to minimize bias and accurately portray information (Silverman 2007).

\section{CONCLUSION}

Adaptive environmental governance faces many challenges stemming from the complexity of SESs and human decision making. We outline several principles of cognition and social cognition in decision making that may influence the nature and trajectory of societal adaptation, particularly proposed legal reforms. By considering these major cognitive and social cognitive barriers to adaptation, legal scholars, policymakers, and practitioners might be better equipped to find constructive ways to address them in research and practice.

Responses to this article can be read online at: http://www.ecologyandsociety.org/issues/responses. php/9154

\section{Acknowledgments:}

We thank Barbara Cosens and two anonymous reviewers for their helpful feedback on earlier drafts of this article. This research is part of a synthesis project on social-ecological system resilience, climate change, and adaptive water governance, co-chairs B. Cosens and L. Gunderson, with the National Socio-Environmental Synthesis Center (SESYNC) under funding from the National Science Foundation DBI-1052875. The views expressed in this paper are those of the authors and do not represent the views or policies of the U.S. Environmental Protection Agency.

\section{LITERATURE CITED}

Abrams, D., M. Wetherell, S. Cochrane, M. A. Hogg, and J. C. Turner. 1990. Knowing what to think by knowing who you are: self-categorization and the nature of norm formation, conformity, and group polarization. British Journal of Social Psychology 29:97-119. http://dx.doi.org/10.1111/j.2044-8309.1990. tb00892.X

Adams, W., and D. Hulme. 2001. Conservation and community: changing narratives, policies and practices in African conservation. Pages 9-23 in D. Hulme, and M. W. Murphree, editors. African wildlife and livelihoods: the promise and performance of community conservation. Heinemann, Portsmouth, New Hampshire, USA.

Anderies, J. M., M. A. Janssen, F. Bousquet, J.-C. Cardenas, D. Castillo, M.-C. Lopez, R. Tobias, B. Vollan, and A. Wutich. 2011. The challenge of understanding decisions in experimental studies of common pool resource governance. Ecological Economics 70:1571-1579. http://dx.doi.org/10.1016/j.ecolecon.2011.01.011

Armitage, D. 2007. Governance and the commons in a multi-level world. International Journal of the Commons 2(1):7-32. http://dx. doi.org/10.18352/ijc. 28

Arnold, C. A. 2004. Working out an environmental ethic: anniversary lessons from Mono Lake. Wyoming Law Review 4:1-55. [online] URL: http://www.monobasinresearch.org/ images/legal/arnoldethic.pdf

Arnold, C. A. 2014. Framing watersheds. Pages 271-302 in K. H. Kirokawa, editor. Environmental law and contrasting ideas of nature: a constructivist approach. Cambridge University Press, Cambridge, Massachusetts, USA. http://dx.doi.org/10.1017/ cbo9781139519762.015

Arnold, C. A., O. O. Green, D. DeCaro, A. Chase, and J.-G. Ewa. 2014. The social-ecological resilience of an eastern urbansuburban watershed: the Anacostia River Basin. Idaho Law Review 51(1):29-90. http://dx.doi.org/10.2139/ssrn.2584968

Arnold, C. A., and L. H. Gunderson. 2013. Adaptive law and resilience. Environmental Law Reporter 43:10426-10443. [online] URL: https://www.researchgate.net/publication/257109831_Adaptive Law and Resilience

Arnstein, S. R. 1969. A ladder of citizen participation. Journal of the American Institute of Planners 35:216-224. http://dx.doi. org/10.1080/01944366908977225 
Attari, S. Z., M. Schoen, C. I. Davidson, M. L. DeKay, W. B. de Bruin, R. Dawes, and M. J. Small. 2009. Preferences for change: do individuals prefer voluntary actions, soft regulations, or hard regulations to decrease fossil fuel consumption? Ecological Economics 68(6):1701-1710. http://dx.doi.org/10.1016/j. ecolecon.2008.10.007

Bailey, K., and T. Grossardt. 2010. Toward structured public involvement: justice, geography and collaborative/geovisual decision support systems. Annals of the Association of American Geographers 100(1):57-86. http://dx.doi.org/10.1080/00045600903364259

Bauer, M. W. and G. Gaskell. 2008. Social representations theory: a progressive research programme for social psychology. Journal For The Theory of Social Behaviour 38(4):335-353. http://dx.doi. org/10.1111/j.1468-5914.2008.00374.X

Bator, R. J., and R. B. Cialdini. 2000. The application of persuasion theory to the development of effective proevironmental public service announcements. Journal of Social Issues 56 (3):527-541. http://dx.doi.org/10.1111/0022-4537.00182

Beach, L. R. 1998. Image theory: theoretical and empirical foundations. Routledge, Newark, New Jersey, USA.

Benson, M. H., D. Llewellyn, R. Morrison, and M. Stone. 2014. Water governance challenges in New Mexico's Middle Rio Grande Valley: a resilience assessment. Idaho Law Review 51:195-228. http://dx.doi.org/10.2139/ssrn.2464387

Beratan, K. K. 2007. A cognition-based view of decision processes in complex social-ecological systems. Ecology and Society 12 (1):27. http://dx.doi.org/10.5751/ES-02103-120127

Berrone, P., L. Gelabert, and A. Fosfuri. 2009. The impact of symbolic and substantive actions on environmental legitimacy. IESE Business School Working Paper 778. IESE Business School, University of Navarra, Barcelona, Spain. http://dx.doi. org/10.2139/ssrn.1349063

Bingham, L. B. 2009. Collaborative governance: emerging practices and the incomplete legal framework for public and stakeholder voice. Missouri Journal of Dispute Resolution 2009 (2):1-58. [online] URL: https://papers.ssrn.com/sol3/papers.cfm? abstract $\mathrm{id}=1162409$

Bingham, L. B. 2010. The next generation of administrative law: building the legal infrastructure for collaborative governance. Wisconsin Law Review 297(2). [online] URL: https://papers.ssrn. com/sol3/papers.cfm?abstract $\mathrm{id}=1646725$

Bingham, L. B., T. Nabatchi, and R. O'Leary. 2005. The new governance: practices and processes for stakeholder and citizen participation in the work of government. Public Administration Review 65(5):547-558. http://dx.doi.org/10.1111/j.1540-6210.2005.00482. $\underline{\mathrm{x}}$

Birgé, H. E., C. R. Allen, R. K. Craig, A. S. Garmestani, J. A. Hamm, C. Babbitt, K. Nemec, and E. Schlager. 2014. Socialecological resilience and law in the Platte River Basin. Idaho Law Review 51(1):229-256.

Bowles, S. 2008. Policies designed for self-interested citizens may undermine "the moral sentiments": evidence from economic experiments. Science 320:1605-1609. http://dx.doi.org/10.1126/ science. 1152110
Boykoff, M. T., and J. M. Boykoff. 2004. Balance as bias: global warming and the US prestige press. Global Environmental Change 14(2):125-136. http://dx.doi.org/10.1016/j.gloenvcha.2003.10.001

Brehm, S. S., and J. W. Brehm. 1981. Psychological reactance: a theory of freedom and control. Academic, New York, New York, USA.

Brittain, A., and S. Rich. 2015. Is D.C.'s 5-cent fee for plastic bags actually serving its purpose? Washington Post 9 May. [online] URL: https://www.washingtonpost.com/investigations/nickelby-nickel-is-the-dc-bag-fee-actually-saving-the-anacostia-river/2015/05/09/ d63868d2-8a18-11e4-8ff4-fb93129c9c8b story.html

Bullard, R. D., and G. S. Johnson. 2000. Environmental justice: grassroots activism and its impact on public policy decision making. Journal of Social Issues 56(3):555-578. http://dx.doi. org/10.1111/0022-4537.00184

Cialdini, R. B. 2003. Crafting normative messages to protect the environment. Current Directions in Psychological Science 12 (4):105-109. http://dx.doi.org/10.1111/1467-8721.01242

Camerer, C. F., and G. Loewenstein. 2004. Behavioral economics: past, present, future. Pages 3-51 in C. F. Camerer, G. Lowenstein, and M. Rabin, editors. Advances in behavioral economics. Princeton University Press, New York, New York, USA.

Castro, P. 2006. Applying social psychology to the study of environmental concern and environmental worldviews: some contributions from social representations approach. Journal of Community and Applied Social Psychology 16:247-266. http://dx. doi.org/10.1002/casp.864

Castro, P. 2012. Legal innovation for social change: exploring change and resistance to different types of sustainability laws. Political Psychology 33(1):105-121. http://dx.doi.org/10.1111/ j.1467-9221.2011.00863.X

Castro, P., and S. Batel. 2008. Social representation, change and resistance: on the difficulties of generalizing new norms. Culture and Psychology 14(4):475-497. http://dx.doi.org/10.1177/1354067x08096512

Castro, P., and C. Mouro. 2011. Psycho-social processes in dealing with legal innovation in the community: insights from biodiversity conservation. American Journal of Community Psychology 47 (3-4):362-373. http://dx.doi.org/10.1007/s10464-010-9391-0

Castro, P., M. Garrido, E. Reis, and J. Menezes. 2009. Ambivalence and conservation behaviour: an exploratory study on the recycling of metal cans. Journal of Environmental Psychology 29(1):24-33. http://dx.doi.org/10.1016/j.jenvp.2008.11.003

Chaffin, B. C., R. K. Craig, and H. Gosnell. 2014b. Resilience, adaptation, and transformation in the Klamath River Basin social-ecological system. Idaho Law Review 51(1):157-193. [online] URL: https://papers.ssrn.com/sol3/papers.cfm? abstract $\mathrm{id}=2449381$

Chaffin, B. C., H. Gosnell, and B. A. Cosens. 2014a. A decade of adaptive governance scholarship: synthesis and future directions. Ecology and Society 19(3):56. http://dx.doi.org/10.5751/ ES-06824-190356

Chaffin, B. C., and L. H. Gunderson. 2016. Emergence, institutionalization and renewal: rhythms of adaptive governance 
in complex social-ecological systems. Environmental Management 165:81-87. http://dx.doi.org/10.1016/j.jenvman.2015.09.003

Chase, L. C, W. F. Siemer, and D. J. Decker. 2002. Designing stakeholder involvement strategies to resolve wildlife management controversies. Wildlife Society Bulletin 30 (3):937-950.

Chen, X.-P., M. M. Pillutla, and X. Yao. 2009. Unintended consequences of cooperation inducing and maintaining mechanisms in public goods dilemmas: sanctions and moral appeals. Group Processes and Intergroup Relations 12(2):241-255. http://dx.doi.org/10.1177/1368430208098783

Chess, C., and K. Purcell. 1999. Public participation and the environment: do we know what works? Environmental Science and Technology 33(16):2685-2692. http://dx.doi.org/10.1021/es980500g

Chokshi, N. 2016. "Turn off the computer," Oregon sheriff begs. Stop "tearing each other apart." Post Nation 12 February. [online] URL: https://www.washingtonpost.com/news/post-nation/wp/2016/02/12/ turn-off-the-computer-oregon-sheriff-begs-stop-tearing-each-otherapart/

Clarvis, M. H., A. Allan, and D. M. Hannah. 2014. Water, resilience and the law: from general concepts and governance design principles to actionable mechanisms. Environmental Science and Policy 43:98-110. http://dx.doi.org/10.1016/j. envsci.2013.10.005

Clement, F. 2010. Analysing decentralised natural resource governance: proposition for a "politicised" institutional analysis and development framework. Policy Sciences 43(2):129-156. http://dx.doi.org/10.1007/s11077-009-9100-8

Colquitt, J. A. 2001. On the dimensionality of organizational justice: a construct validation of a measure. Journal of Applied Psychology 86(3):386-400. http://dx.doi.org/10.1037//0021-9010.86.3.386

Cookey, P. E., R. Darnsawasdi, and C. Ratanachai. 2016. A conceptual framework for assessment of governance performance of lake basins: towards transformation to adaptive and integrative governance. Hydrology 3(1):12. http://dx.doi. org/10.3390/hydrology3010012

Convery, F. J., and S. McDonnell. 2003. Applying environmental product taxes and levies - lessons from the experience with the Irish Plastic Bags Levy. Fourth annual global conference on environmental taxation. University of Technology, Sydney, Australia.

Cornforth, A. 2009. Behaviour change: insights for environmental policy making from social psychology and behavioural economics. Policy Quarterly 5(4):21-28. [online] URL: http://ips. ac.nz/publications/files/5831f842e9c.pdf

Cosens, B. A. 2013. Legitimacy, adaptation, and resilience in ecosystem management. Ecology and Society 18(1):3. http://dx. doi.org/10.5751/ES-05093-180103

Cosens, B. A., R. K. Craig, S. Hirsch, C. A. (T.) Arnold, M. H. Benson, D. A. DeCaro, A. S. Garmestani, H. Gosnell, J. Ruhl, and E. Schlager. 2017. The role of law in adaptive governance. Ecology and Society 22(1):30. http://dx.doi.org/10.5751/ $\underline{\text { es-08731-220130 }}$
Cosens, B. A., and A. K. Fremier. 2014. Assessing system resilience and ecosystem services in large river basins: a case study of the Columbia River Basin. Idaho Law Review 51(1):91-125. [online] URL: https://www.uidaho.edu/ /media/UIdaho-Responsive/ Files/law/law-review/articles/volume-51/51-1-cosens-barbara-etal. $\underline{\operatorname{ashx}}$

Cosens, B. A., L. Gunderson, and B. Chaffin. 2014a. The Adaptive Water Governance Project: assessing law, resilience and governance in regional social-ecological water systems facing changing climate. Idaho Law Review 51(1):1-27. [online] URL: https://papers.ssrn.com/sol3/papers.cfm?abstract id=2519236

Cosens, B. A., L. Gunderson, C. Allen, and M. H. Benson. $2014 b$. Identifying legal, ecological and governance obstacles, and opportunities for adapting to climate change. Sustainability 6 (4):2338-2356. http://dx.doi.org/10.3390/su6042338

Cote, M., and A. J. Nightingale. 2012. Resilience thinking meets social theory situating social change in socio-ecological systems (SES) research. Progress in Human Geography 36(4):475-489. http://dx.doi.org/10.1177/0309132511425708

Cox, M., G. Arnold, and S. V. Tomás. 2010. A review of design principles for community-based natural resource management. Ecology and Society 15(4):38. http://dx.doi.org/10.5751/ ES-03704-150438

Craig, R. K. 2010. Stationarity is dead: long live transformation: five principles for climate change adaptation law. Harvard Environmental Law Review 34(1):9-75. [online] URL: http://www. law.harvard.edu/students/orgs/elr/vol34 1/9-74.pdf

Craig, R. K., A. S. Garmestani, C. R. Allen, C. A. Arnold, H. Birgé, D. A. DeCaro, A. K. Fremier, H. Gosnell, and E. Schlager. 2017. Balancing stability and flexibility in adaptive governance: an analysis of tools available in U.S. environmental law. Ecology and Society: in press.

Craig, R. K., and J. B. Ruhl. 2014. Designing administrative law for adaptive management. Vanderbilt Law Review 67(1):1-87. http://dx.doi.org/10.2139/ssrn.2222009

Davidson, D. J. 2010. The applicability of the concept of resilience to social systems: some sources of optimism and nagging doubts. Society and Natural Resources 23(12):1135-1149. http://dx.doi. org/10.1080/08941921003652940

DeCaro, D. A., B. C. Chaffin, E. Schlager, A. S. Garmestani, and J. B. Ruhl. 2017. Legal and institutional foundations of adaptive environmental governance. Ecology and Society 22(1):32. http:// dx.doi.org/10.5751/es-09036-220132

DeCaro, D. A., M. A. Janssen, and A. Lee. 2015. Synergistic effects of voting and enforcement on internalized motivation to cooperate in a resource dilemma. Judgment and Decision Making 10(6):511-537. [online] URL: http://journal.sjdm.org/15/15529/ jdm15529.html

DeCaro, D. A., and M. Stokes. 2008. Social-psychological principles of community-based conservation and conservancy motivation: attaining goals within an autonomy-supportive environment. Conservation Biology 22(6):1443-1451. http://dx. doi.org/10.1111/j.1523-1739.2008.00996.x 
DeCaro, D. A., and M. K. Stokes. 2013. Public participation and institutional fit: a social-psychological perspective. Ecology and Society 18(4):40. http://dx.doi.org/10.5751/ES-05837-180440

Deci, E. L., and R. M. Ryan. 1987. The support of autonomy and the control of behavior. Journal of Personality and Social Psychology 53(6):1024-1037. http://dx.doi.org/10.1037/0022-3514.53.6.1024

Deci, E. L., R. Koestner, and R. M. Ryan. 1999. The undermining effect is a reality after all - extrinsic rewards, task interest, and self-determination: reply to Eisenberger, Pierce, and Cameron (1999) and Lepper, Henderlong, and Gingras (1999). Psychological Bulletin 125:692-700. http://dx.doi. org/10.1037/0033-2909.125.6.692

Deci, E. L., and R. M. Ryan. 2000. The "what" and "why" of goal pursuits: human needs and the self-determination of behavior. Psychological Inquiry 11:227-268. http://dx.doi.org/10.1207/ S15327965PLI1104 01

De Cremer, D., and T. R. Tyler. 2005. Managing group behavior: the interplay between procedural justice, sense of self, and cooperation. Advances in Experimental Social Psychology 37:151-218. http://dx.doi.org/10.1016/S0065-2601(05)37003-1

Dietz, T., E. Ostrom, and P. C. Stern. 2003. The struggle to govern the commons. Science 302:1907-1912. http://dx.doi.org/10.1126/ $\underline{\text { science. } 1091015}$

Dingfelder, S. 2004. Clark honored for desegregation influence, life's work. Monitor on Psychology 35(8):59.

Dollar, C. B., and B. Ray. 2015. The practice of reintegrative shaming in mental health court. Criminal Justice Policy Review 26(1):29-44. http://dx.doi.org/10.1177/0887403413507275

Doremus, H. 2003. Takings and transitions. Journal of Land Use and Environmental Law 19:1-46.

Doremus, H., and M. Hanemann. 2007. The challenges of dynamic water management in the American West. UCLA Journal of Environmental Law and Policy 25(2):55-75.

Druschke, C. G., and K. C. Hychka. 2015. Manager perspectives on communication and public engagement in ecological restoration project success. Ecology and Society 20(1):58. http:// dx.doi.org/10.5751/es-07451-200158

Dunlap, R. E., and A. M. McCright. 2010. Climate change denial: sources, actors and strategies. Pages 240-259 in C. Lever-Tracy, editor. Routledge handbook of climate change and society. Routledge, Abingdon, UK. http://dx.doi.org/10.4324/9780203876213. $\underline{\operatorname{ch} 14}$

Edelman, M. 1960. Symbols and political quiescence. American Political Science Review 54(03):695-704. http://dx.doi.org/10.1017/ $\underline{\mathrm{S} 0003055400122646}$

Edelman, M. 1985. The symbolic uses of politics. University of Illinois Press, Chicago, Illinois, USA.

Epstein, G. 2017. Local rulemaking, compliance and conditional cooperation in state-owned forest commons. Ecological Economics 131:312-321. http://dx.doi.org/10.1016/j.ecolecon.2016.09.012
Epstein, G., J. Pittman, S. M. Alexander, S. Berdej, T. Dyck, U. Kreitmair, K. J. Raithwell, S. Villamayor-Tomas, J. Vogt, and D. Armitage. 2015. Institutional fit and the sustainability of socialecological systems. Current Opinion in Environmental Sustainability 14:34-40. http://dx.doi.org/10.1016/j.cosust.2015.03.005

Esty, D. C. 2006. Good governance at the supranational scale: globalizing administrative law. Yale Law Journal 115:1490-1562. http://dx.doi.org/10.2307/20455663

Fabinyi, M., L. Evans, and S. J. Foale. 2014. Social-ecological systems, social diversity, and power: insights from anthropology and political ecology. Ecology and Society 19(4):28. http://dx.doi. org/10.5751/es-07029-190428

Fairweather, G. W., and W. S. Davidson. 1986. An introduction to community experimentation theory, methods, and practice. McGraw-Hill, New York, New York, USA.

Farrell, J. 2016. Corporate funding and ideological polarization about climate change. Proceedings of the National Academy of Sciences 113(1):92-97. http://dx.doi.org/10.1073/pnas.1509433112

Felson, A. J., and S. T. A. Pickett. 2005. Designed experiments: new approaches to studying urban ecosystems. Frontiers in Ecology and the Environment 3:549-556. http://dx.doi. org/10.1890/1540-9295(2005)003[0549:DENATS]2.0.CO;2

Folke, C., T. Hahn, P. Olsson, and J. Norberg. 2005. Adaptive governance of social-ecological systems. Annual Reviews of Environment and Resources 30:441-473. http://dx.doi.org/10.1146/ annurev.energy.30.050504.144511

Frey, B. S., M. Benz, and A. Stutzer. 2004. Introducing procedural utility. Not only what, but also how matters. Journal of Institutional and Theoretical Economics 160:377-401. http://dx. doi.org/10.1628/0932456041960560

Fung, A. 2006. Varieties of participation in complex governance. Public Administration Review 66(1):66-75. http://dx.doi. org/10.1111/j.1540-6210.2006.00667.x

Gächter, S. 2007. Conditional cooperation. Pages 19-50 in B. S. Frey and A. Stutzer, editors. Economics and psychology: a promising new cross-disciplinary field. MIT Press, Cambridge, Massachusetts, USA.

Gattig, A., and L. Hendrickx. 2007. Judgmental discounting and environmental risk perception: dimensional similarities, domain differences, and implications for sustainability. Journal of Social Issues 63(1):21-39. http://dx.doi.org/10.1111/j.1540-4560.2007.00494. $\underline{x}$

Gerlak, A. K., and T. Heikkila. 2011. Building a theory of learning in collaboratives: evidence from the Everglades restoration program. Journal of Public Administration Research 21:619-644. http://dx.doi.org/10.1093/jopart/muq089

Gifford, R. 2011. The dragons of inaction: psychological barriers that limit climate change mitigation and adaptation. American Psychologist 66(4):290-302. http://dx.doi.org/10.1037/a0023566

Gigerenzer, G., and P. M. Todd. 1999. Fast and frugal heuristics: the adaptive toolbox. Pages 2-34 in G. Gigerenzer, P. M. Todd, and the ABC Reseach Group. Simple heuristics that make us smart. Oxford University Press, New York, New York, USA. 
Goldstein, E. B. 2011. Problem solving. Pages 324-358 in E. B. Goldstein, editor. Cognitive psychology: connecting mind, research, and everyday experience. Wadsworth, Belmont, California, USA.

Gray, S. A., S. Gray, J. L. De Kok, A. E. R. Helfgott, B. O’Dwyer, R. Jordan, and A. Nyaki. 2015. Using fuzzy cognitive mapping as a participatory approach to analyze change, preferred states, and perceived resilience of social-ecological systems. Ecology and Society 20(2):11. http://dx.doi.org/10.5751/es-07396-200211

Green, O. O., A. S. Garmestani, C. R. Allen, L. H. Gunderson, J. B. Ruhl, C. A. Arnold, N. A. J. Graham, B. Cosens, D. G. Angeler, B. C. Chaffin, and C. S. Holling. 2015. Barriers and bridges to the integration of social-ecological resilience and law. Frontiers in Ecology and the Environment 13(6):332-337. http://dx. doi.org/10.1890/140294

Gromet, D. M., H. Kunreuther, and R. P. Larrick. 2013. Political ideology affects energy-efficiency attitudes and choices. Proceedings National Academy Sciences 110(23):9314-9319. http://dx.doi.org/10.1073/pnas.1218453110

Gunderson, L. H., A. Garmestani, K. W. Rizzardi, J. B. Ruhl, and A. Light. 2014. Escaping a rigidity trap: governance and adaptive capacity to climate change in the Everglades social ecological system. Idaho Law Review 51:127-156. [online] URL: https://www.cfr.washington.edu/courses/seminars/lance-gundersonescaping-a-rigidity-trap.pdf

Hardin, G. 1968. Tragedy of the commons. Science 162 (13):1243-1248. http://dx.doi.org/10.1126/science.162.3859.1243

Hardisty, D. J., E. J. Johnson, and E. U. Weber. 2010. A dirty word or a dirty world? Attribute framing, political affiliation, and query theory. Psychological Science 21(1):86-92. http://dx.doi. org/10.1177/0956797609355572

Heikkila, T., E. Schlager, and M. W. Davis. 2011. The role of crossscale institutional linkages in common pool resource management: assessing interstate river compacts. Policy Studies Journal 39(1):121-145. http://dx.doi.org/10.1111/j.1541-0072.2010.00399. $\underline{\mathrm{X}}$

Hilbe, C., A. Traulsen, T. Röhl, and M. Milinski. 2014. Democratic decisions establish stable authorities that overcome the paradox of second-order punishment. Proceedings of the National Academies of Science 111(2):752-756. http://dx.doi. org/10.1073/pnas.1315273111

Hobbes, T. 1651/1909. Leviathan. Oxford, Clarendon, UK.

Howard, J. L. 2010. Managing for justice in community-based water planning: a conceptual framework. Environmental Conservation 37(3):356-363. http://dx.doi.org/10.1017/s0376892910000627

Huber, B. R. 2011. Transition policy in environmental law. Harvard Environmental Law Review 35:91-130. [online] URL: http://scholarship.law.nd.edu/law faculty scholarship/480/

Huitema, D., E. Mostert, W. Egas, S. Moellenkamp, C. PahlWostl, and R. Yalcin. 2009. Adaptive water governance: assessing the institutional prescriptions of adaptive (co-)management from a governance perspective and defining a research agenda. Ecology and Society 14(1):26. http://dx.doi.org/10.5751/ES-02827-140126
Hunt, L., and W. Haider. 2011. Fair and effective decision making in forest management planning. Society and Natural Resources 14:873-887. http://dx.doi.org/10.1080/089419201753242788

Irvin, R. A., and J. Stansbury. 2004. Citizen participation in decision making: is it worth the effort? Public Administration Review (64)1:55-65. http://dx.doi.org/10.1111/j.1540-6210.2004.00346. $\underline{\mathrm{X}}$

Jung, J. Y., and B. A. Mellers. 2016. American attitudes toward nudges. Judgment and Decision Making 11(1):62-74. [online] URL: http://journal.sjdm.org/15/15824a/jdm15824a.pdf

Kahneman, D. 2003. A perspective on judgment and choice: mapping bounded rationality. American Psychologist 58 (9):697-720. http://dx.doi.org/10.1037/0003-066x.58.9.697

Kemp, R., J. Schot, and R. Hoogma. 1998. Regime shifts to sustainability through processes of niche formation: the approach of strategic niche management. Technology Analysis and Strategic Management 10(2):175-198. http://dx.doi.org/10.1080/09537329$\underline{808524310}$

Kenney, D. S. 2000. Arguing about consensus: examining the case against western watershed initiatives and other collaborative groups active in natural resources management. Natural Resources Law Center, University of Colorado School of Law Boulder, Colorado, USA. [online] URL: http://scholar.law.colorado.edu/ cgi/viewcontent.cgi?article $=1032 \&$ context=books reports studies.

Kim, E.-H., and T. P. Lyon. 2013. Beyond the dichotomy of symbolic versus substantive actions. Academy of Management Proceedings 1:14398. http://dx.doi.org/10.5465/ambpp.2013.14398abstract

Kinzig, A. P., P. R. Ehrlich, L. J. Alston, K. Arrow, S. Barrett, T. G. Buchman, G. C. Daily, B. Levin, S. Levin, M. Oppenheimer, E. Ostrom, and D. Saari. 2013. Social norms and global environmental challenges: the complex interaction of behaviors, values, and policy. BioScience 63(3):164-175. http://dx.doi. org/10.1525/bio.2013.63.3.5

Klein, G. 1999. The recognition-primed decision model. Pages 15-30 in Sources of power: how people make decisions. MIT press, Cambridge, Massachusetts, USA.

Kollmuss, A., and J. Agyeman. 2002. Mind the gap: why do people act environmentally and what are the barriers to proenvironmental behavior? Environmental Education Research 8 (3):239-260 http://dx.doi.org/10.1080/13504620220145401

Korobkin, R. B. 2003. The endowment effect and legal analysis. Northwestern University Law Review 97:1227-1291. [online] URL: https://papers.ssrn.com/sol3/papers.cfm?abstract_id=326360

Kosters, M., and J. Van der Heijden. 2015. From mechanism to virtue: evaluating Nudge theory. Evaluation 21(3):276-291. http:// dx.doi.org/10.1177/1356389015590218

Krause, R. M. 2011. Symbolic or substantive policy? Measuring the extent of local commitment to climate protection. Environment and Planning C: Government and Policy 29(1):46-62. http://dx.doi.org/10.1068/c09185

Kubo, H., and B. Supriyanto. 2010. From fence-and-fine to participatory conservation: mechanisms of transformation in 
conservation governance at the Gunung Halimun-Salak National Park, Indonesia. Biodiversity and Conservation 19(6):1785-1803. http://dx.doi.org/10.1007/s10531-010-9803-3

Larson, K. L., A. Wiek, and L. W. Keeler. 2013. A comprehensive sustainability appraisal of water governance in Phoenix, AZ. Journal of Environmental Management 116:58-71. http://dx.doi. org/10.1016/j.jenvman.2012.11.016

Lavergne, K. J., E. C. Sharp, L. G. Pelletier, and A. Holtby. 2010. The role of perceived government style in the facilitation of selfdetermined and non self-determined motivation for proenvironmental behavior. Journal of Environmental Psychology 30:169-177. http://dx.doi.org/10.1016/j.jenvp.2009.11.002

Lawrence, R. L., S. E. Daniels, and G. H. Stankey. 1997. Procedural justice and public involvement in natural resource decision making. Society and Natural Resources 10:577-589. http://dx.doi.org/10.1080/08941929709381054

Leach, W. D., and P. A. Sabatier. 2005. To trust an adversary: integrating rational and psychological models of collaborative policymaking. American Political Science Review 99(04):491-503. http://dx.doi.org/10.1017/s000305540505183x

Leach, W. D., C. M. Weible, S. R. Vince, S. N. Siddiki, and J. C. Calanni. 2013. Fostering learning through collaboration: knowledge acquisition and belief change in marine aquaculture partnerships. Journal of Public Administration Research Theory 24:591-622. http://dx.doi.org/10.1093/jopart/mut011

Lee, V. K., and L. T. Harris. 2013. How social cognition can inform social decision making. Frontiers in Neuroscience 7(259):1-13. https://doi.org/10.3389/fnins.2013.00259

Leonard, T. C. 2008. Richard H. Thaler, Cass R. Sunstein, Nudge: improving decisions about health, wealth, and happiness. Constitutional Political Economy 19(4):356-360. http://dx.doi. org/10.1007/s10602-008-9056-2

Leotti, L. A., S. S. Iyengar, and K. N. Ochsner. 2010. Born to choose: the origins and value of the need for control. Trends in Cognitive Science 14(10):457-463. http://dx.doi.org/10.1016/j. tics.2010.08.001

Lever-Tracy, C., editor. 2010. Routledge Handbook of Climate Change and Society. Routledge, New York, New York, USA.

Levine, J. M. 1999. Solomon Asch's legacy for group research. Personality and Social Psychology Review 3(4):358-364. http://dx. doi.org/10.1207/s15327957pspr0304_5

Lichtenstein, S., P. Slovic, B. Fischhoff, M. Layman, and B. Combs. 1978. Judged frequency of lethal events. Journal of Experimental Psychology: Human Learning and Memory 4:551-578. http://dx.doi.org/10.1037/0278-7393.4.6.551

Lind, E. A., and K. van den Bos. 2002. When fairness works: toward a general theory of uncertainty management. Research in Organizational Behavior 24:181-223. http://dx.doi.org/10.1016/ S0191-3085(02)24006-X

Lockwood, M. 2010. Good governance for terrestrial protected areas: a framework, principles and performance outcomes. Journal of Environmental Management 91:754-766. http://dx.doi. org/10.1016/j.jenvman.2009.10.005
Loewenstein, G. F., E. U. Weber, C. K. Hsee, and N. Welch. 2001. Risk as feelings. Psychological Bulletin 127(2):267-286. http://dx. doi.org/10.1037/0033-2909.127.2.267

Long, N. E. 1958. The local community as an ecology of games. American Journal of Sociology 64(3):251-261. http://dx.doi. org/10.1086/222468

Lubell, M. 2004. Collaborative environmental institutions: all talk and no action? Journal of Policy Analysis and Management 23(3):549-573. http://dx.doi.org/10.1002/pam.20026

Lubell, M., A. D. Henry, and M. McCoy. 2010. Collaborative institutions in an ecology of games. American Journal of Political Science 54(2):287-300. http://dx.doi.org/10.1111/j.1540-5907.2010.00431. $\underline{\mathrm{x}}$

Luyet, V., R. Schlaepfer, M. B. Parlange, and A. Buttler. 2012. A framework to implement stakeholder participation in environmental projects. Journal of Environmental Management 111:213-219. http://dx.doi.org/10.1016/j.jenvman.2012.06.026

Lydon, M., D. Bartman, R. Woudstra, and A. Khawarzad. 2010. Tactical urbanism: short term action: long term change. Volume 1. Street Plans Collaborative, Brooklyn, New York, USA. [online] URL: http://issuu.com/streetplanscollaborative/docs/ tactical urbanism vol.1 http://dx.doi.org/10.5822/978-1-61091-567-0

Malone, E. L., R. Diamond, A. K. Wolfe, T. Sanquist, C. Payne, and J. Dion. 2013. Implementing sustainability: the behavioralinstitutional dimension. Sustain 28(Spring/Summer):28-32. [online] URL: https://www.researchgate.net/publication/255814673 Implementing_Sustainability the Behavioral-

Institutional Dimension

Margerum, R. D. 2008. A typology of collaboration efforts in environmental management. Environmental Management 41:487-500. http://dx.doi.org/10.1007/s00267-008-9067-9

Markussen, T., L. Putterman, and J.-R. Tyran. 2014. Selforganization for collective action: an experimental study of voting on sanction regimes. Review of Economic Studies 81(1):301-324. https://doi.org/10.1093/restud/rdt022

Marshall, G. 2008. Nesting, subsidiarity, and community-based environmental governance beyond the local scale. International Journal of the Commons 2(1):75-97. http://dx.doi.org/10.18352/ ijc. 50

McComas, K. A., R. Stedman, and P. S. Hart. 2011. Community support for campus approaches to sustainable energy use: the role of "town-gown" relationships. Energy Policy 39:2310-2318. http://dx.doi.org/10.1016/j.enpol.2011.01.045

McCright, A. M., C. Xiao, and R. E Dunlap. 2014. Political polarization on support for government spending on environmental protection in the USA, 1974-2012. Social Science Research 48:251-260. http://dx. doi.org/10.1016/j.ssresearch.2014.06.008

McCusker, C., and P. J. Carnevale. 1995. Framing in resource dilemmas: loss aversion and the moderating effect of sanctions. Organizational Behavior and Human Decision Processes 61:190-201. http://dx.doi.org/10.1006/obhd.1995.1015

McGinley, P. C. 2011. Climate change and the war on coal: exploring the dark side. Vermont Journal of Environmental Law 
13:255-331. http://vjel.vermontlaw.edu/publications/climate-changeand-the-war-on-coal-exploring-the-dark-side/

McKenzie-Mohr, D. 2000. Promoting sustainable behavior: an introduction to community-based social marketing. Journal of Social Issues 56(3):543-554. http://dx.doi.org/10.1111/0022-4537.00183

McKenzie-Mohr, D. 2013. Fostering sustainable behavior. Sustain: a journal of environmental and sustainability issues 28 (Spring/Summer):43-52.

Medin, D. L., and M. H. Bazerman. 1999. Broadening behavioral decision research: multiple levels of cognitive processing. Psychonomic Bulletin and Review 6(4):533-546. http://dx.doi. org/10.3758/bf03212961

Meyer, J. W., and B. Rowan. 1977. Institutionalized organizations: formal structure as myth and ceremony. American Journal of Sociology 83(2):340-363. http://dx.doi.org/10.1086/226550

Milinski, M., D. Semmann, and H.-J. Krambeck. 2002. Reputation helps solve the 'tragedy of the commons.' Nature 415 (24):424-426. http://dx.doi.org/10.1038/415424a

Moghaddam, F. M. 2008. The psychological citizen and the two concepts of social contract: a preliminary analysis. Political Psychology 29(6):881-901. http://dx.doi.org/10.1111/ j.1467-9221.2008.00671.x

Moller, A. C., R. M. Ryan, and E. L. Deci. 2006. Selfdetermination theory and public policy: improving the quality of consumer decisions without using coercion. Journal of Public Policy and Marketing 25(1):104-116. http://dx.doi.org/10.1509/ jppm.25.1.104

Monroe, M. C., E. Andrews, and K. Biedenweg. 2008. A framework for environmental education strategies. Applied Environmental Education and Communication 6(3-4):205-216. http://dx.doi.org/10.1080/15330150801944416

Moscovici, S. 1988. Notes towards a description of social representations. European Journal of Social Psychology 18 (3):211-250. http://dx.doi.org/10.1002/ejsp.2420180303

Moser, S. C., and J. A. Ekstrom. 2010. A framework to diagnose barriers to climate change adaptation. Proceedings of the National Academy of Sciences 107(51):22026-22031. http://dx.doi. org/10.1073/pnas. 1007887107

Moskowitz, P. 2014. Cold weather snap fuels misinformation over climate change. Aljeezera America. 5 January. [online] URL: http://america.aljazeera.com/articles/2014/1/5/cold-weathersnapbringsconfusionoverclimatechange.html

Mulder, L. B., E. van Dijk, D. De Cremer, and H. A. M. Wilke. 2006. Undermining trust and cooperation: the paradox of sanctioning systems in social dilemmas. Journal of Experimental Social Psychology 42:147-162. http://dx.doi.org/10.1016/j. jesp.2005.03.002

Munaretto, S., G. Siciliano, and M. E. Turvani. 2014. Integrating adaptive governance and participatory multicriteria methods: a framework for climate adaptation governance. Ecology and Society 19(2):74. http://dx.doi.org/10.5751/es-06381-190274

National Civic League (NCL). 2013. Making public participation legal. National Civic League, Denver, Colorado, USA. [online] URL: http://ncdd.org/rc/wp-content/uploads/MakingP2Legal. pdf
Nickerson, R. S. 1998. Confirmation bias: a ubiquitous phenomenon in many guises. Review of General Psychology 2 (2):175-220. http://dx.doi.org/10.1037/1089-2680.2.2.175

O'Leary, R., L. B. Bingham, and Y. Choi. 2010. Teaching collaborative leadership: ideas and lessons for the field. Journal of Public Affairs Education 16(4):565-592. [online] URL: https:// www.researchgate.net/publication/259854481_Teaching_Collaborative Leadership Ideas and Lessons for the Field

Opotow, S., and A. Brook. 2003. Identity and exclusion in rangeland conflict. Pages 249-272 in S. Clayton and S. Opotow, editors. Identity and natural environment: the psychological significance of Nature. MIT Press, Cambridge, Massachusetts, USA.

Ostrom, E. 1965. Public entrepreneurship: a case study in ground water management. Dissertation. University of California at Los Angeles, Los Angeles, California, USA. [online] URL: https://dlc. dlib.indiana.edu/dlc/handle/10535/3581

Ostrom, E. 1990. Governing the commons: evolution of institutions for collective action. Cambridge University Press, Cambridge, UK.

Ostrom, E. 1994. Crafting institutions for self-governing irrigation systems. Institute for Contemporary Studies, Oakland, California, USA.

Ostrom, E. 1998. A behavioral approach to the rational choice theory of collective action: presidential address: American Political Science Association 1997. American Political Science Review 91:1-22. http://dx.doi.org/10.2307/2585925

Ostrom, E. 2000. Crowding out citizenship. Scandinavian Political Studies 23(1):3-16. http://dx.doi.org/10.1111/1467-9477.00028

Ostrom, E. 2005. Animating institutional analysis. Pages 99-133 in E. Ostrom, editor. Understanding institutional diversity. Princeton University Press, Princeton, New Jersey, USA.

Ostrom, E. 2007. A diagnostic approach for going beyond panaceas. Proceedings of the National Academy of Sciences 104 (39):15181-15187. http://dx.doi.org/10.1073/pnas.0702288104

Ostrom, E. 2010. Beyond markets and states: polycentric governance of complex economic systems. American Economic Review 100:641-672. http://dx.doi.org/10.1257/aer.100.3.641

Ostrom, E. 2014. Do institutions for collective action evolve? Journal of Bioeconomics 16:3-30. http://dx.doi.org/10.1007/ $\underline{\text { s10818-013-9154-8 }}$

Ostrom, V. 1971. The political theory of a compound republic: designing the American experiment. Second edition. Institute for Contemporary Studies, Oakland, California, USA.

Ostrom, V. 1994. The meaning of American federalism: constituting a self-governing society. Institute for Contemporary Studies, Oakland, California, USA.

Pahl-Wostl, C. 2009. A conceptual framework for analysing adaptive capacity and multi-level learning processes in resource governance regimes. Global Environmental Change 19(3):354-365. http://dx.doi.org/10.1016/j.gloenvcha.2009.06.001

Pahl-Wostl, C., G. Holtz, B. Kastens, and C. Knieper. 2010. Analyzing complex water governance regimes: the management 
and transition framework. Environmental Science and Policy 13:571-581. http://dx.doi.org/10.1016/j.envsci.2010.08.006

Parks, C. D., J. Joireman, and P. A. M. Van Lange. 2013. Cooperation, trust, and antagonism: how public goods are promoted. Psychological Science in the Public Interest 14 (3):119-165. http://dx.doi.org/10.1177/1529100612474436

Pelletier, L. G. 2002. A motivational analysis of selfdetermination for pro-environmental behaviors. Pages 205-232 in E. L. Deci and R. M. Ryan, editors. Handbook of selfdetermination research. University Of Rochester Press, Rochester, New York, USA.

Peluso, N. L. 1993. Coercing conservation? The politics of state resource control. Global Environmental Change 3(2):199-217. http://dx.doi.org/10.1016/0959-3780(93)90006-7

Poteete, A. R., M. A. Janssen, and E. Ostrom. 2010. Pushing the frontiers of the theory of collective action and the commons. Pages 215-247 in A. R. Poteete, M. A. Janssen, and E. Ostrom, editors. Working together: collective action, the commons, and multiple methods in practice. Princeton University Press, Princeton, New Jersey, USA.

Quinn, P. 2011. A sea change off the coast of Maine: common pool resources as cultural property. Emory Law Journal 60:1323-1388. [online] URL: https://papers.ssrn.com/sol3/ papers.cfm?abstract $\mathrm{id}=1701225$

Rachlinski, J. J. 1999. Limits of social norms. Chicago-Kent Law Review 74:1537-1567. [online] URL: http://scholarship.law. cornell.edu/facpub/815/

Rachlinski, J. J. 2000. The psychology of global climate change. University of Illinois Law Review 1:299-319. [online] URL: http:// scholarship.law.cornell.edu/facpub/792/

Rachlinski, J. J. 2012. Selling heuristics. Alabama Law Review 64:389-415. [online] URL: https://www.law.ua.edu/pubs/lrarticles/ Volume $\% 2064 /$ Issue $\% 202 / 5 \% 20$ Rachlinski $\% 20389 \% 20-\% 20415 \%$ 20Final $\%$ 20CROPPED.pdf

Reed, M. S. 2008. Stakeholder participation for environmental management: a literature review. Biological Conservation 141:2417-2431. http://dx.doi.org/10.1016/j.biocon.2008.07.014

Reynolds, T. W., A. Bostrom, D. Read, and M. G. Morgan. 2010. Now what do people know about global climate change? Survey studies of educated laypeople. Risk Analysis 30(10):1520-1538. http://dx.doi.org/10.1111/j.1539-6924.2010.01448.x

Ruhl, J. B. 2011. General design principles for resilience and adaptive capacity in legal systems: applications to climate change adaptation law. North Carolina Law Review 89:1374-1401. [online] URL: https://papers.ssrn.com/sol3/papers.cfm?abstract id=1694187

Rustagi, D., E. Engel, and M. Kosfeld. 2010. Conditional cooperation and costly monitoring explain success in forest commons management. Science 330(6006):961-965. http://dx. doi.org/10.1126/science.1193649

Ryan, R. L., and E. L. Deci. 2006. Self-regulation and the problem of human autonomy: does psychology need choice, selfdetermination, and will? Journal of Personality 74(6):1557-1586. http://dx.doi.org/10.1111/j.1467-6494.2006.00420.x
Sarker, A. 2013. The role of state-reinforced self-governance in averting the tragedy of the irrigation commons in Japan. Public Administration 91(3):727-743 http://dx.doi.org/10.1111/padm.12011

Sarkki, S., L. Rantala, and T. P. Karjalainen. 2015. Fit between conservation instruments and local social systems: cases of comanagement and payments for ecosystem services. Change and Adaptation in Socio-Ecological Systems 2(1):59-78. http://dx.doi. org/10.1515/cass-2015-0007

Schlager, E. and T. Heikkila. 2011. Left high and dry? Climate change, common-pool resource theory, and adaptability of Western water compacts. Public Administration Review 71 (3):461-470. http://dx.doi.org/10.1111/j.1540-6210.2011.02367.x

Schlager, E., T. Heikkila, and C. Case. 2012. The costs of compliance with interstate agreements: lessons from water compacts in the western United States. Publius 42(3):494-515. http://dx.doi.org/10.1093/publius/pjs017

Schlichting, I. 2013. Strategic framing of climate change by industry actors: a meta-analysis. Environmental Communication 7(4):493-511. http://dx.doi.org/10.1080/17524032.2013.812974

Sheldon, K. M., A. J. Elliot, Y. Kim, and T. Kasser. 2001. What is satisfying about satisfying events? Testing 10 candidate psychological needs. Journal of Personality and Social Psychology 80(2):325-339. http://dx.doi.org/10.1037/0022-3514.80.2.325

Shilling, F. M., J. K. London, and R. S. Liévanos. 2009. Marginalization by collaboration: environmental justice as a third party in and beyond CALFED. Environmental Science and Policy 12(6):694-709. http://dx.doi.org/10.1016/j.envsci.2009.03.003

Shivakumar, S. 2005. The constitution of development: crafting capabilities for self-governance. Palgrave Macmillan, New York, New York, USA. http://dx.doi.org/10.1057/9781403982117

Siddiki, S., X. Basurto, and C. M. Weible. 2012. Using the institutional grammar tool to understand regulatory compliance: the case of Colorado aquaculture. Regulation and Governance 6 (2):167-188. http://dx.doi.org/10.1111/j.1748-5991.2012.01132.x

Silbey, S. S. 1989. A sociological interpretation of the relationship between law and society. Pages 1-27 in R. J. Neuhaus, editor. Law and the Ordering of Our Life Together. William B. Eerdmans, Grand Rapids, Michigan, USA.

Silverman, C. 2007. Regret the error: how media mistakes pollute the press and imperil free speech. Union Square, New York, New York, USA.

Sinner, J., and G. Salmon. 2003. Creating economic incentives for sustainable development: a report to the New Zealand Business Council for Sustainable Development. Nelson, Ecologic Foundation, Nelson, New Zealand. [online] URL: https://www. sbc.org.nz/ data/assets/pdf_file/0009/99423/Incentives-for-SD-full. pdf

Smith, V. 2012. Analysis: 'war on coal' label belies realities. Lexington Herald Leader 22 October. [online] URL: http://www. kentucky.com/news/business/article44384148.html

Steg, L., and C. Vlek. 2009. Encouraging pro-environmental behavior: an integrative review and research agenda. Journal of Environmental Psychology 29:309-317. http://dx.doi.org/10.1016/ j.jenvp.2008.10.004 
Stern, P. C. 2011. Contributions of psychology to limiting climate change. American Psychologist 66(4):303-314. http://dx.doi. org/10.1037/a0023235

Stern, P. C., and W. E. Easterling. 1999. Making climate forecasts matter. National Academies, Washington, D.C., USA. https:// doi.org/10.17226/6370

Stoknes, P. E. 2014. Rethinking climate communications and the "psychological climate paradox." Energy Research and Social Science 1:161-170. http://dx.doi.org/10.1016/j.erss.2014.03.007

Sugihara, G., R. May, H. Ye, C.-H. Hsieh, E. Deyle, M. Fogarty, and S. Munch. 2012. Detecting causality in complex ecosystems. Science 338(6106):496-500. http://dx.doi.org/10.1126/science.1227079

Sunstein, C. R. 2000. Deliberative trouble? Why groups go to extremes. Yale Law Journal 110:71-119. http://dx.doi. org/10.2307/797587

Sutinen, J. G., and K. Kuperan. 1999. A socio-economic theory of regulatory compliance. International Journal of Social Economics 26(1/2/3):174-193. http://dx.doi.org/10.1108/0306829$\underline{9910229569}$

Swim, J. K., P. C. Stern, T. J. Doherty, S. Clayton, J. P. Reser, E. U. Weber, R. Gifford, and G. S. Howard. 2011. Psychology's contributions to understanding and addressing global climate change. American Psychologist 66(4):241-250. http://dx.doi. org/10.1037/a0023220

Syme, G. J., B. E. Nancarrow, and J. A. McCreddin. 1999. Defining the components of fairness in the allocation of water to environmental and human uses. Journal of Environmental Management 57(1):51-70. http://dx.doi.org/10.1006/jema.1999.0282

Tenbrunsel, A. E., and D. M. Messick. 1999. Sanctioning systems, decision frames, and cooperation. Administrative Science Quarterly 44(4):684-707. http://dx.doi.org/10.2307/2667052

Thaler, R. H., and C. R. Sunstein. 2008. Nudge: improving decisions about health, wealth, and happiness. Yale University Press, New Haven, Connecticut, USA.

Turner, R. A., C. Fitzsimmons, J. Forster, R. Mahon, A. Peterson, and S. M. Stead. 2014. Measuring good governance for complex ecosystems: perceptions of coral reef-dependent communities in the Caribbean. Global Environmental Change 29:105-117. http:// dx.doi.org/10.1016/j.gloenvcha.2014.08.004

Turnhout, E., S. Van Bommel, and N. Aarts. 2010. How participation creates citizens: participatory governance as performative practice. Ecology and Society 15(4):26 http://dx.doi. org/10.5751/ES-03701-150426

Tversky, A., and D. Kahneman. 1981. The framing of decisions and the psychology of choice. Science 211(4481):453-458.

Tyler, T. R. 1988. What is procedural justice?: criteria used by citizens to assess the fairness of legal procedures. Law and Society Review 22:103-136. http://dx.doi.org/10.2307/3053563

Tyler, T. R. 1990. Why people obey the law. Yale University Press, New Haven, Connecticut, USA.

Tyler, T. R. 2006. Psychological perspectives on legitimacy and legitimization. Annual Reviews of Psychology 57:375-400. http:// dx.doi.org/10.1146/annurev.psych.57.102904.190038
Tyler, T. R., and P. Degoey. 1995. Collective restraint in social dilemmas: procedural justice and social identification effects on support for authorities. Journal of Personality and Social Psychology 69(3):482-497. http://dx.doi.org/10.1037/0022-3514.69.3.482

Tyran, J.-R., and L. P. Feld. 2006. Achieving compliance when legal sanctions are non-deterrent. Scandinavian Journal of Economics 108(1):135-156. http://dx.doi.org/10.1111/ j.1467-9442.2006.00444.X

von Korff, Y., P. d'Aquino, K. A. Daniell, and R. Bijlsma. 2010. Designing participation processes for water management and beyond. Ecology and Society 15(3):1. http://dx.doi.org/10.5751/ ES-03329-150301

Van Ness, D. W., and K. H. Strong. 2013. Restoring justice: an introduction to restorative justice. Routledge, New York, New York, USA. [online] URL: http://www.sciencedirect.com/science/ book/9781455731398

van Prooijen, J.-W. 2009. Procedural justice as autonomy regulation. Journal of Personality and Social Psychology 96 (6):1166-1180. http://dx.doi.org/10.1037/a0014153

Vreudenhil, H., J. Slinger, E. Kater, and W. Thissen. 2010. The influence of scale preferences on the design of a water innovation: a case in Dutch river management. Environmental Management 46(1):29-43. http://dx.doi.org/10.1007/s00267-010-9524-0

Weber, E. U. 2010. What shapes perceptions of climate change? Wiley Interdisciplinary Reviews: Climate Change 1(3):332-342. http://dx.doi.org/10.1002/wcc.41

Weber, E. U., and P. C. Stern. 2011. Public understanding of climate change in the United States. American Psychologist 66 (4):315-328. http://dx.doi.org/10.1037/a0023253

Westley, F. R, P. Olsson, C. Folke, T. Homer-Dixon, H. Vredenburg, D. Loorbach, J. Thompson, M. Nilsson, E. Lambin, J. Sendzimir, B. Banerjee, V. Galaz, and S. van der Leeuw. 2011. Tipping toward sustainability: emerging pathways of transformation. Ambio 40:762-780. http://dx.doi.org/10.1007/ s13280-011-0186-9

Westley, F. R., O. Tjornbo, L. Schultz, P. Olsson, C. Folke, B. Crona and Ö. Bodin. 2013. A theory of transformative agency in linked social-ecological systems. Ecology and Society 18(3):27. http://dx.doi.org/10.5751/es-05072-180327

Westphal, J. D., and E. J. Zajac. 2013. A behavioral theory of corporate governance: explicating the mechanisms of socially situated and socially constituted agency. Academy of Management Annals 7(1):607-661. http://dx.doi.org/10.1080/19416520.2013.783669

White House, Office of the Press Secretary. 2015. Executive order - using behavioral science insights to better serve the American people. White House, Washington, D.C., USA. [online] URL: https://obamawhitehouse.archives.gov/the-press-office/2015/09/15/ executive-order-using-behavioral-science-insights-better-serve-american

Winter, D. D. N. 2000. Some big ideas for some big problems. American Psychologist 55(5):516-522. http://dx.doi. org/10.1037/0003-066x.55.5.516

Wood, W., G. J. Pool, K. Leck, and D. Purvis. 1996. Self-definition, defensive processing, and influence: the normative impact of 
majority and minority groups. Journal of Personality and Social Psychology 71:1181-1193. http://dx.doi.org/10.1037/0022-3514.71.6.1181

Yamagishi, T. 1986. The provision of a sanctioning system as a public good. Journal of Personality and Social Psychology 51 (1):110-116. http://dx.doi.org/10.1037/0022-3514.51.1.110

Yee, V. 2012. No appetite for good-for-you school lunches. New York Times 5 October. [online] URL: http://www.nytimes. com/2012/10/06/nyregion/healthier-school-lunches-face-studentrejection.html 